\title{
Ligand-Induced Internalization of the p75 Neurotrophin Receptor: A Slow Route to the Signaling Endosome
}

\author{
Francisca C. Bronfman, ${ }^{1}$ Marianna Tcherpakov, ${ }^{1}$ Thomas M. Jovin, ${ }^{2}$ and Mike Fainzilber ${ }^{1}$ \\ ${ }^{1}$ Molecular Neurobiology Group, Department of Biological Chemistry, Weizmann Institute of Science, 76100 Rehovot, Israel, and ${ }^{2}$ Department of Molecular \\ Biology, Max Planck Institute for Biophysical Chemistry, D-37077 Goettingen, Germany
}

The nerve growth factor (NGF) family of neurotrophins binds two classes of cell-surface receptors, trk receptor tyrosine kinases and the shared p75 receptor. Rapid internalization and retrograde trafficking of neurotrophin-trk complexes have been demonstrated in a number of systems and are thought to transmit trophic signals from terminals to neuronal cell bodies. In contrast, the internalization and trafficking of neurotrophin-p75 complexes are not well understood. In this study, we used biotinylated NGF and a fluorescent-labeled anti-p75 antibody to follow the kinetics and route of ligand-induced internalization of the p75 receptor in cycling and differentiated PC12 cells. Binding of neurotrophins to p75 induced internalization at a rate approximately three times slower than that of transferrin and NGF-TrkA complexes in the same cells. The ligand-p75 complex was internalized via clathrin-coated pits into early endosomes and eventually accumulated in recycling endosomes in the cell body and vesicles colabeled by the cholera toxin B-subunit in the growth cones. Both internalized ligand and $\mathrm{p} 75$ were protected from proteolytic degradation and accumulated in vesicles that did not undergo acidification. Finally, NGF induced endosomal association of p75 and its MAGE interactors, necdin and NRAGE. These data suggest that signaling endosomes containing activated p 75 are involved in neurotrophin signaling, and that such endosomes may be temporally and spatially distinct from those containing trk receptors.

Key words: neurotrophin; p75 receptor; retrograde transport; internalization; recycling endosome; signaling endosome

\section{Introduction}

The nerve growth factor (NGF) family of neurotrophins interacts with specific members of the trk family of receptor tyrosine kinases to signal differentiation or survival of neuronal cells (Patapoutian and Reichardt, 2001). In addition, all neurotrophins bind to a shared p75 receptor (Hutson and Bothwell, 2001) that also binds other ligands (Fainzilber et al., 1996; Tuffereau et al., 1998; Della-Bianca et al., 2001; Lee et al., 2001). p75 has diverse roles in the nervous system, ranging from enhancement of axonal outgrowth through modulation of cell survival or cell death (Lee et al., 2001; Hempstead, 2002).

Neurotrophin signaling via trk receptors ultimately leads to activation of transcription factors, most notably cAMP response element-binding protein (CREB) (Riccio et al., 1997, 1999; Lonze et al., 2002). This nuclear response requires transduction of the target-derived neurotrophin signal along the full length of the axon (for review, see Miller and Kaplan, 2001; Neet and Campenot, 2001; Ginty and Segal, 2002; Heerssen and Segal, 2002). Proposed mechanisms for such retrograde transduction include calcium/phosphorylation "waves" progressing along the axon (Senger and Campenot, 1997; MacInnis and Campenot, 2002),

\footnotetext{
Received Dec. 12, 2002; revised Jan. 23, 2003; accepted Jan. 28, 2003.

This work was supported by Grant GR-1802 from the German and Israeli Ministries of Science (M.F., T.M.J.), Grant 647/01 from the Israel Science Foundation (M.F.), and an EMBO short-term fellowship and Feinberg postdoctoral fellowship (F.C.B.) M.F. is the incumbent of the Daniel Koshland Sr. Career Development Chair at the Weizmann Institute. We thank Dr. Phil Barker, Dr. Louis Reichardt, and Dr. Kazuaki Yoshikawa for generous provision of antibodies. We are grateful to Dr. Dmitry Charny (Goettingen, Germany) for advice on NGF labeling, Dr. Vladimir Kiss (Rehovot, Israel) for assistance with confocal microscopy, and Zehava Levy for excellent technical assistance.

Correspondence should be addressed to Mike Fainzilber, Department of Biological Chemistry, Weizmann Institute of Science, Herzl Street 1, 76100 Rehovot, Israel. E-mail: mike.fainzilber@weizmann.ac.il.

Copyright $\odot 2003$ Society for Neuroscience $\quad 0270-6474 / 03 / 233209-12 \$ 15.00 / 0$
}

axonal transport of activated signaling molecules (Kuruvilla et al., 2000; Watson et al., 2001), or retrograde transport of activated neurotrophin-trk complexes (Bhattacharyya et al., 1997; TsuiPierchala and Ginty, 1999; Watson et al., 1999). The latter possibility has been elaborated as the "signaling endosome" hypothesis (Di Fiore and De Camilli, 2001). Potential TrkA-signaling endosomes in PC12 cells contain NGF and activated TrkA, are internalized via clathrin-coated pits, and are associated with activated signaling proteins of the Ras-MAP kinase pathway (Grimes et al., 1997; Howe et al., 2001). A direct interaction between trk receptors and dynein has been reported previously (Yano et al., 2001), providing a possible mechanism for trafficking of trk-signaling endosomes.

In contrast to the detailed studies on trk retrograde signaling, evidence for ligand-induced internalization and trafficking of the p75 receptor is rather weak. Anti-p75 monoclonal antibodies have been used to target toxins into cholinergic neurons (Heckers et al., 1994; Berger-Sweeney et al., 2001), and p75 may be involved in neurotrophin trafficking in certain neuronal subtypes (Curtis et al., 1995; von Bartheld et al., 1996; Kramer et al., 1999; Butowt and von Bartheld, 2001; Gatzinsky et al., 2001). However, a number of studies have failed to establish a role for p75 in NGF internalization (Eveleth and Bradshaw, 1992; Kahle et al., 1994; Gargano et al., 1997). Recent studies have emphasized independent signaling roles for p75 in both the nervous and vascular systems (Kaplan and Miller, 2000; von Schack et al., 2001; Hempstead, 2002). These findings, and the fact that p75 lacks intrinsic catalytic activities, rekindles the question as to how ligand binding to p75 might transmit a retrograde signal. We have addressed this issue by directly examining ligand-induced internalization of p75. Neurotrophin-p75 complexes internalize slowly and accu- 
mulate in nonacidified vesicles in PC12 cells. NGF enhances association of p75 with intracellular interactors on these vesicles, thus defining signaling endosomes that may be temporally and spatially distinct from those containing trk receptors.

\section{Materials and Methods}

Reagents. EZ-link biotin-PEO-amine (amino-biotin), 1-ethyl-3-(3dimethyl aminopropyl)carbodiimide (EDC), and 2(4' -hydroxyazobenzene) benzoic acid (HABA) were from Pierce (Rockford, IL). Mouse NGF and the MC192 anti-p75 antibody conjugated to FITC were from Alomone Labs (Jerusalem, Israel). Recombinant human BDNF was a generous gift from Dr. Carlos Ibanez (Karolinska Institute, Stockholm, Sweden). Transferrin-Alexa-594, transferrin-Alexa-547, streptavidinAlexa-594, streptavidin-Alexa-647, B-subunit of cholera toxin-Alexa594, and LysoTracker Red DND-99 were from Molecular Probes (Eugene, OR). Rhodamine Red-X (RRX)-conjugated donkey-anti-goat, RRX-anti-mouse, goat RRX-anti-horseradish peroxidase (HRP), Cy5conjugated donkey anti-rabbit, anti-goat and anti-mouse, IgG rat transferrin-HRP, and protease-free bovine serum albumin (BSA) were from Jackson ImmunoResearch (West Grove, PA). Rab7, Rab5, cathepsin D, hemagglutinin (HA), pan trk (C14), tyrosine-phospho-specific rabbit polyclonals, Clathrin heavy chain (Clathrin $\mathrm{HC}$ ) goat polyclonal, and pan trk monoclonal (B3) were from Santa Cruz Biotechnology (Santa Cruz, CA). Early endosomal autoantigen1 (EEA1) rabbit polyclonal was from Affinity BioReagents (Golden, CO). Rabbit anti-p75 intracellular domain and neurotrophin receptor-interacting MAGE homolog (NRAGE) polyclonals were from Dr. Philip Barker (Montreal Neurological Institute, Montreal, Canada), rabbit anti-necdin was from Dr. Kazuaki Yoshikawa (Osaka University, Osaka, Japan), and rabbit r-TrkA polyclonal was from Dr. Louis Reichardt (University of California, San Francisco, San Francisco, CA). Magnetic particles were from Roche Products (Hertforshire, UK). The ABC/peroxidase kit was from Dako (Copenhagen, Denmark). All other reagents were from Sigma (St. Louis, $\mathrm{MO})$.

Cell culture. PC12 cells were grown in DMEM containing glutamine and high glucose and supplemented with $6 \%$ horse serum, $6 \%$ fetal calf serum, and $100 \mathrm{U} / \mathrm{ml}$ penicillin-streptomycin. For differentiation experiments, cells were seeded at a concentration of $10-15,000$ cells per square centimeter on poly-D-lysine-coated $16 \mathrm{~mm}$ coverslips and maintained for $4-5 \mathrm{~d}$ in the presence of $4 \mathrm{~nm}$ NGF in complete media. Differentiation was scored by morphological criteria and AChE activity determination (Bronfman et al., 2000). PC12-nnr5 (nnr5) cells were grown in collagencoated dishes in RMPI-1640 media containing $4 \mathrm{~mm}$ glutamine, supplemented with $5 \%$ horse serum, $10 \%$ fetal calf serum and $100 \mathrm{U} / \mathrm{ml}$ penicillin-streptomycin. PC12 cells stably transfected with necdin-HA were established as described previously (Tcherpakov et al., 2002). Transient transfections of COS cells were with DEAE-dextran.

NGF iodination. NGF was iodinated by the lactoperoxidase method as described previously (Ryden et al., 1997). Steady-state competitionbinding assays were performed on cells suspended in PBS supplemented with $1 \mathrm{mg} / \mathrm{ml} \mathrm{BSA}, 1 \mathrm{mM} \mathrm{MgCl}_{2}$, and $0.5 \mathrm{mM} \mathrm{CaCl}_{2}$ in the presence or absence of native or biotinylated NGF. Binding was allowed to occur with gentle rocking at $4^{\circ} \mathrm{C}$ for $90 \mathrm{~min}$, and the bound ligand was separated from free ligand by rapid pelleting of the cells in an Eppendorf microfuge (Eppendorf Scientific, Westbury, NY) at $4^{\circ} \mathrm{C}$.

NGF biotinylation. The water-soluble carbodiimide EDC can mediate coupling between free amine and carboxyl groups to form an amide linkage. We took advantage of this property to selectively biotinylate NGF on carboxyl groups, by reacting EDC with NGF in the presence of EZ-link biotin-PEO-amine. NGF $(0.5 \mathrm{mg})$ was dissolved together with 20 $\mathrm{mg}$ of amino-biotin in $710 \mu \mathrm{l}$ of MES-NaOH buffer, pH 5.0. Forty microliters of EDC ( $0.5 \mathrm{M})$ were added to this solution, and the reaction was allowed to proceed for $2 \mathrm{hr}$ with vigorous shaking at room temperature (RT). Biotinylated NGF (NGFb) was then purified from the reaction mixture by reverse-phase HPLC over a C4 column (Vydac) and quantified by spectroscopy. The degree of NGF biotinylation was then measured by competitive displacement of HABA dye from avidin, yielding an average 9.2 mol biotin per mole NGF.
NGFb binding and internalization in PC12 and nnr5 cells. Cells were grown in monolayers and harvested in PBS with 2 mM EDTA, pelleted, and resuspended in ice-cold DMEM HEPES with $1 \mathrm{mg} / \mathrm{ml} \mathrm{BSA}$ and 4-6 nм NGFb. Cells from one confluent plate $\left(6-9 \times 10^{6}\right.$ cells $)$ were used for each experimental point. $\mathrm{NGFb}$ was allowed to bind for $90 \mathrm{~min}$ at $4^{\circ} \mathrm{C}$ with gentle rotation, followed by four washes in PBS. The final cell pellet was resuspended in lysis buffer, composed of $20 \mathrm{~mm}$ Tris-HCl, $\mathrm{pH} 8.0$, $150 \mathrm{~mm} \mathrm{NaCl}, 0.1 \%$ Igepal, 10\% glycerol, 2 mм EDTA, and protease inhibitors mix (Roche Products). After clearing by 15 min centrifugation at $18,000 \times g$, the supernatant was adsorbed with streptavidin magnetic particles (Roche Products) overnight at $4^{\circ} \mathrm{C}$. The particles were washed three times in lysis buffer for $10 \mathrm{~min}$ at $4^{\circ} \mathrm{C}$, followed by one wash in water. Bound NGFb was then eluted by 10 min of boiling in $100 \mu \mathrm{l}$ of SDS-PAGE sample buffer, followed by separation on $17.5 \%$ SDS-PAGE and blotting to nitrocellulose. NGFb was visualized with $\mathrm{ABC} /$ peroxidase using enhanced chemiluminescence (ECL) detection (Pierce). For internalization experiments, cells were incubated for the desired times $(2-180$ $\min$ ) at $37^{\circ} \mathrm{C}$, followed by rapid chilling on ice and centrifugation for 2 $\mathrm{min}$ at $1200 \times \mathrm{g}$. Cell pellets were then acid washed by resuspension in 0.2 $\mathrm{M}$ acetic acid and $0.5 \mathrm{M} \mathrm{NaCl}$ for $7 \mathrm{~min}$ on ice, followed by three PBS washes. Internalized NGFb was then identified by lysis of the cell pellet and streptavidin pull-downs as described above. The band corresponding to NGFb was quantified with Image Gauge V3.41 software (Fuji, Tokyo, Japan) and regression analysis of the curves obtained was performed as described by Shogomori and Futerman (2001).

Tyrosine phosphorylation and Western blot analysis for TrkA. PC12 cells were treated with NGF at the indicated concentrations for $15 \mathrm{~min}$ at $37^{\circ} \mathrm{C}$, washed with ice-cold PBS, and lysed with $10 \mathrm{~mm}$ Tris, $\mathrm{pH} 8.0,150$ $\mathrm{mm} \mathrm{NaCl}, 10 \%$ glycerol, $1 \mathrm{~mm}$ orthovanadate, and proteinase inhibitors (Roche Products) containing $0.1 \%$ Igepal. Lysates were spun at 10,000 $\times$ $g$ for $5 \mathrm{~min}$ and then precleared with $100 \mu \mathrm{l}$ of a $50 \%$ suspension of protein-A agarose beads (Roche Products) for $1 \mathrm{hr}$ at $4^{\circ} \mathrm{C}$. The beads were removed and the supernatant $(1 \mathrm{ml})$ was incubated with $6 \mu \mathrm{g}$ of $\mathrm{C} 14$ primary antibody overnight at $4^{\circ} \mathrm{C}$, followed by $100 \mu \mathrm{l}$ of protein- $\mathrm{A}$ agarose for $1 \mathrm{hr}$ at $4^{\circ} \mathrm{C}$. Beads were precipitated and washed three times in lysis buffer, and proteins were eluted by $10 \mathrm{~min}$ of boiling in $60 \mu \mathrm{l}$ of SDS-PAGE sample buffer, followed by separation on $10 \%$ SDS-PAGE and blotting to nitrocellulose. Tyrosine phosphorylation of immunoprecipitated TrkA was determined with a specific phosphotyrosine antibody and a secondary antibody conjugated to HRP and developed with ECL. The presence of TrkA in transfected COS cells was determined by immunoprecipitation as described above and development of the nitrocellulose membrane with a pan trk B3 monoclonal.

Immuno-endocytosis assay. MC192-FITC was used in an immunoendocytosis assay to visualize ligand-induced internalization of p75. PC12 or nnr 5 cells were seeded onto poly-D-lysine-coated coverslips at high density and used for endocytosis assays after $24-48 \mathrm{hr}$. Cells were cultured as described above with the exception that the DMEM medium did not contain phenol red. After preincubation for $1 \mathrm{hr}$ at $37^{\circ} \mathrm{C}$ with incubation buffer (DMEM HEPES, $1 \mathrm{mg} / \mathrm{ml} \mathrm{BSA}$ ) to deplete endogenous transferrin and growth factors, cells were incubated with MC192-FITC $(3 \mu \mathrm{g} / \mathrm{ml})$, NGF $(6-20 \mathrm{~nm})$, and transferrin-Alexa-647 $(60 \mu \mathrm{g} / \mathrm{ml})$ in incubation buffer for $15-180 \mathrm{~min}$ at $37^{\circ} \mathrm{C}$, followed by three washes in ice-cold PBS and fixation in 3\% paraformaldehyde for $20 \mathrm{~min}$. The fixation reaction was quenched in $0.1 \mathrm{~mm}$ glycine for $10 \mathrm{~min}$. Cells were then washed in PBS and incubated for $60 \mathrm{~min}$ at RT with Cy5 or RRX anti-mouse (1:500; to label cell surface-associated MC192), washed, and mounted in Moviol. For cointernalization studies of p75 and NGF, differentiated PC12 cells were incubated with MC192-FITC $(3 \mu \mathrm{g} / \mathrm{ml})$ and $\mathrm{NGFb}(20 \mathrm{~nm})$ for $90 \mathrm{~min}$ at $4^{\circ} \mathrm{C}$, followed by $30 \mathrm{~min}$ incubation with streptavidin-Alexa-647 (1:100) in the presence of NGF (6 nM). Cells were then washed three times with PBS, and the coverslip was inverted in 100 $\mu \mathrm{l}$ ice-cold incubation buffer in a silicon rubber chamber on a microscope slide. Internalization was then induced by warming the slide for $10-60 \mathrm{~min}$ at $37^{\circ} \mathrm{C}$, followed by in vivo visualization of the cells.

Fluorescence microscopy and quantitative analysis. Labeled cells were examined under an Olympus (Olympus Optical, Tokyo, Japan) laserscanning microscope FV500 equipped with an Olympus IX70 inverted microscope (Olympus Optical) and Argon ion $488 \mathrm{~nm}$, He-Ne $543 \mathrm{~nm}$, 
and He-Ne $633 \mathrm{~nm}$ lasers. For fluorescein, Rhodamine Red-X and Alexa594, Alexa-647, and Cy5 visualization, BA505IF, BA610If, and BA610IF filters were used.

Digital images of cell-associated fluorescence were acquired with a high-aperture objective (PLAPO 60×, numerical aperture 1.4). To quantify the fluorescence intensity associated with cells after MC192-FITC, transferrin-Alexa-647, and HRP internalization, six to eight digital images were taken from at least two different coverslips at $6 \times$ magnification for each time point. Cells presenting good morphology in phase images were chosen without bias as to their level of fluorescence and optically sectioned at $1 \mu \mathrm{m}$ resolution. A total of $12-15$ cells were imaged per experimental point. Cell-associated fluorescence was quantified with Fluoview Olympus (Olympus Optical) software station, after cell borders were defined with the help of the contrast phase image. Total cellular fluorescence was determined after subtracting nonspecific fluorescence of images obtained with the same illumination and exposure conditions in untreated cells.

Internalized transferrin and HRP were expressed as total cellular fluorescence (arbitrary units). Internalized MC192-FITC was expressed as a ratio of the internalized receptor (intracellular fluorescence) versus the cell surface-associated receptor (cell surface-associated fluorescence). Cell surface-associated MC192 was labeled by incubation with Cy5 or RRX-conjugated anti-mouse. Absence of internalization was defined as the fluorescence value obtained with cells treated with MC192-FITC for $90 \mathrm{~min}$ at $4^{\circ} \mathrm{C}$. This value was subtracted from the different time points at $37^{\circ} \mathrm{C}$. The regression analysis of the curves obtained was performed according to Shogomori and Futerman (2001). Colocalization of MC192FITC and transferrin-Alexa-647 was quantified with ImagePro Plus software (Media Cybernetics, Silver Spring, MD).

Cointernalization of TrkA and p75. Differentiated PC12 cells were treated with MC192-FITC ( $3 \mu \mathrm{g} / \mathrm{ml}$, green), r-TrkA antibody (1:500) (Clary et al., 1994), and BDNF (4 nM) for $60 \mathrm{~min}$ at $4^{\circ} \mathrm{C}$; washed and incubated for $30 \mathrm{~min}$ at $4^{\circ} \mathrm{C}$ with anti-rabbit-Cy5 $(1: 250$, red) and BDNF (4 nM); and then washed and incubated for different times (15-60 min) at $37^{\circ} \mathrm{C}$ in the presence of BDNF ( $4 \mathrm{~nm}$ ). Cells were fixed and mounted as described above. The presence of vesicles positive for $\mathrm{p} 75$ or TrkA, or both, was quantified by measuring the fluorescence intensity levels for each dye (FITC for p75, Cy5 for TrkA) along a line through the respective vesicles. Results are presented as a percentage of total vesicles containing the receptors per cell; $12-15$ different cells were analyzed per time point in each experiment.

Inhibition of receptor-mediated endocytosis via clathrin-coated pits. Internalization via the clathrin route was assessed by two separate methods: potassium depletion (Larkin et al., 1983) and cytosol acidification (Sandvig et al., 1987). All manipulations were performed at $37^{\circ} \mathrm{C}$. Potassium depletion was performed by passing cells through hypotonic medium (DMEM/water, 1:1) for $5 \mathrm{~min}$, followed by $30 \mathrm{~min}$ in potassium depletion buffer (PDF) consisting of $50 \mathrm{~mm}$ HEPES and $100 \mathrm{~mm} \mathrm{NaCl}$, pH 7.4. This was followed by $90 \mathrm{~min}$ of incubation in PDF containing $1 \mathrm{mg} / \mathrm{ml}$

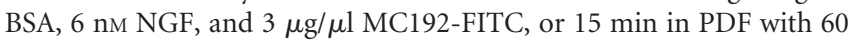
$\mu \mathrm{g} / \mathrm{ml}$ transferrin-Alexa-594 or $2 \mathrm{mg} / \mathrm{ml}$ HRP. Controls underwent the same procedure in PDF supplemented with $10 \mathrm{~mm} \mathrm{KCl}$. For cytosol acidification, cells were incubated for $30 \mathrm{~min}$ in DMEM HEPES, pH 7.0, with $40 \mathrm{~mm} \mathrm{NH}_{4} \mathrm{Cl}$, followed by $5 \mathrm{~min}$ in cytosol acidification buffer (CAB) composed of $20 \mathrm{~mm}$ HEPES, $140 \mathrm{~mm} \mathrm{KCl}, 2 \mathrm{~mm} \mathrm{CaCl}_{2}, 1 \mathrm{~mm}$ $\mathrm{MgCl}_{2}, \mathrm{pH}$ 7.0. p75 internalization was assessed after 90 min of incubation in CAB with $1 \mathrm{mg} / \mathrm{ml} \mathrm{BSA,} 6 \mathrm{~nm}$ NGF, and $3 \mu \mathrm{g} / \mathrm{ml} \mathrm{MC192-FITC,}$ whereas transferrin receptor and HRP internalization were visualized after $15 \mathrm{~min}$ of incubation in CAB containing $60 \mu \mathrm{g} / \mathrm{ml}$ tranferrin-Alexa594 and $2 \mathrm{mg} / \mathrm{ml} \mathrm{HRP}$, respectively. Controls were incubated with the ligands in DMEM HEPES. After the treatments, cells were washed and fixed as described above, followed by 30 min of blocking with $5 \%$ donkey serum in PBS (blocking buffer). Cell surface-associated MC192 was then labeled by $60 \mathrm{~min}$ of incubation with Cy5-conjugated donkey antimouse (1:500), and the cells were then washed and mounted in Moviol for confocal analysis. To visualize HRP, cells were treated as described below for double labeling. Quantification of receptor internalization was performed as described above.
Double labeling. Colocalization of p75 and markers for fluid phase (HRP), early endosomes (EEA1), lysosomes (cathepsin D), late endosomes (rab7), or acid organelles (LysoTracker Red DND-99) was assessed in differentiated PC12 cells. To label early endosomes, cells were incubated for $30 \mathrm{~min}$ at $37^{\circ} \mathrm{C}$ with MC192-FITC ( $\left.3 \mu \mathrm{g} / \mathrm{ml}\right)$, NGF ( $\left.6 \mathrm{nM}\right)$, and HRP $(2 \mathrm{mg} / \mathrm{ml})$. For EEA1, cells were incubated for $60 \mathrm{~min}$ at $37^{\circ} \mathrm{C}$ with MC192-FITC (3 $\mu \mathrm{g} / \mathrm{ml})$ and NGF (6 nM). To label the late endosome and lysosome compartments, cells were first incubated for $15 \mathrm{~min}$ with HRP $(2 \mathrm{mg} / \mathrm{ml})$, washed, and then incubated with MC192-FITC (3 $\mu \mathrm{g} / \mathrm{ml}$ ) and NGF ( $6 \mathrm{nM})$ for $3 \mathrm{hr}$ at $37^{\circ} \mathrm{C}$. For cathepsin D or rab7, cells were incubated with MC192-FITC ( $3 \mu \mathrm{g} / \mathrm{ml})$ and NGF ( $6 \mathrm{nM})$ for $3 \mathrm{hr}$ at $37^{\circ} \mathrm{C}$, followed by fixing and immunostaining with the relevant marker antibody. Cells were blocked for $30 \mathrm{~min}$ in $10 \%$ goat or donkey serum, 1 $\mathrm{mg} / \mathrm{ml} \mathrm{BSA}$, and $0.2 \%$ saponin, followed by $2 \mathrm{hr}$ in $0.05 \%$ saponin and primary antibodies: Rhodamine Red-X-Goat anti-HRP (1/100) or rabbit polyclonals for EEA1 (1/500) cathepsin D and rab7 (1/100). The latter were visualized with Cy5-donkey anti-rabbit (1:100). Loading of acidic organelles with LysoTracker Red DND-99 was performed according to the manufacturer's instructions, followed by wash, fixation, and direct mounting in Moviol. The association of cell-surface p75 after ligand stimulation with clathrin matrices was assessed by patching MC192FITC on the cell surface with rabbit anti-mouse antibody (1:25; Dako), followed by washes and 15 min of incubation at $37^{\circ} \mathrm{C}$ and fixation and immunostaining with goat anti-Clathrin $\mathrm{HC}(1: 250)$ as described above.

Subcellular fractionation. PC12 or PC12-necdin cells (15-20 confluent $10 \mathrm{~cm}$ plates) were preincubated for $1 \mathrm{hr}$ at $37^{\circ} \mathrm{C}$ with incubation buffer (DMEM HEPES, $1 \mathrm{mg} / \mathrm{ml} \mathrm{BSA}$ ) to deplete endogenous transferrin and growth factors, followed by $2 \mathrm{hr}$ at $37^{\circ} \mathrm{C}$ with NGF (4 nM) and $15 \mathrm{~min}$ at $37^{\circ} \mathrm{C}$ with HRP $(1 \mathrm{mg} / \mathrm{ml})$ in the presence of NGF, or $1 \mathrm{hr}$ at $37^{\circ} \mathrm{C}$ with iron-loaded rat transferrin-HRP $(8 \mu \mathrm{g} / \mathrm{ml})$. After labeling, cells were washed extensively with ice-cold PBS and, after a final wash with $320 \mathrm{~mm}$ sucrose and $20 \mathrm{~mm}$ HEPES buffer (HB), pH 7.4, were scraped and sedimented at $800 \times g$ for $5 \mathrm{~min}$. The pellet $(\sim 0.5 \mathrm{ml})$ was resuspended in 1.2 $\mathrm{ml}$ of $\mathrm{HB}$ and homogenized with a ball-bearing homogenizer (cell cracker; European Molecular Biology Laboratory, Heidelberg, Germany) with $12 \mu \mathrm{m}$ clearance. A postnuclear supernatant was prepared by centrifugation for $10 \mathrm{~min}$ at $1000 \times g$ and then additionally centrifuged for $1 \mathrm{hr}$ at $105,000 \times g$ in a TLS 55 rotor (Beckman, Coulter, CA) over $1 \%$ Ficoll in $\mathrm{HB}$ to obtain a $\mathrm{P} 2$ pellet. The $\beta 1$ subunit of $\mathrm{Na}^{+} / \mathrm{K}^{+}$-ATPase was used as a marker for plasma membrane contamination during the subcellular fractionation procedure. $\mathrm{P} 2$ was resuspended in $1 \mathrm{ml} \mathrm{HB}$ and loaded in an $11 \mathrm{ml}$ linear Ficoll gradient prepared in $\mathrm{HB}(1-16 \%)$, the gradient was centrifuged for $3 \mathrm{hr}$ at $210,000 \times \mathrm{g}$ in a SW41 rotor (Beckman), and $1 \mathrm{ml}$ fractions were manually collected from the top. HRP or transferrin-HRP was used to define the early/recycling compartment. The three HRP or transferrin-HRP peak fractions from gradient 1 were pooled and centrifuged over a $9 \mathrm{ml}$ linear Ficoll gradient prepared in HB (3-16\%) for $3 \mathrm{hr}$ at $35,000 \mathrm{rpm}$ in an SW41 rotor, and $1 \mathrm{ml}$ fractions were manually collected from the top (gradient 2). Gradient 2 was free of plasma membrane marker. From cells treated with NGF for $2 \mathrm{hr}$ at $37^{\circ} \mathrm{C}, 70 \mu \mathrm{l}$ of each fraction of gradient 2 were boiled for $10 \mathrm{~min}$ in SDS-PAGE sample buffer and loaded in a $12 \%$ PAGE gel, blotted to nitrocellulose, and probed for rab5 (1:500), p75 (1:1000), NRAGE (1:1000), and necdin (1:5000) or HA- (1:3000) specific antibodies. For coimmunoprecipitation, 5-10 fractions of gradient 2 were pooled and diluted eight times with $\mathrm{HB}$ and then centrifuged for $10-12 \mathrm{hr}$ at $35,000 \mathrm{rpm}$ in an SW41 rotor. The sedimented endosomes were additionally centrifuged for $1 \mathrm{hr}$ at 55,000 $\mathrm{rpm}$ in a TLS 55 rotor and lysed with $10 \mathrm{~mm}$ Tris, $\mathrm{pH} 8.0,150 \mathrm{~mm} \mathrm{NaCl}$, $10 \%$ glycerol, and proteinase inhibitors containing $0.1 \%$ Igepal. Lysates were spun at $10,000 \times g$ for $5 \mathrm{~min}$ and precleared with $30 \mu \mathrm{l}$ of a $50 \%$ suspension of protein-G Sepharose beads (Amersham Biosciences, Arlington Heights, IL) for $30 \mathrm{~min}$ at $4^{\circ} \mathrm{C}$. The beads were removed, and the supernatant $(1 \mathrm{ml})$ was incubated with $5 \mu \mathrm{g}$ of MC192 for $2 \mathrm{hr}$ at $4^{\circ} \mathrm{C}$, followed by $30 \mu \mathrm{l}$ of protein-G Sepharose for $1 \mathrm{hr}$ at $4^{\circ} \mathrm{C}$. Beads were precipitated and washed three times in lysis buffer, and proteins were eluted by $10 \mathrm{~min}$ of boiling with SDS-PAGE sample buffer. Eluted proteins were loaded in a $12 \%$ SDS-PAGE gel, blotted to nitrocellulose, and developed with rabbit anti-NRAGE (1:1000) or anti-HA (1:3000) antibodies. 
HRP activity assay. Each gradient fraction (15-40 $\mu \mathrm{l})$ was brought to $75 \mathrm{ml}$ with lysis buffer and assayed for HRP activity in a 96-well tissueculture plate by the addition of $115 \mu$ l of citrate buffer $(50 \mathrm{~mm}$ citrate/100 $\mathrm{mm} \mathrm{PO}_{4}, \mathrm{pH}$ 5.0), O-phenylenediamine (Sigma), and $0.03 \% \mathrm{H}_{2} \mathrm{O}_{2}$. The assay was stopped with the addition of $60 \mu \mathrm{l}$ of $2 \mathrm{~N} \mathrm{H}_{2} \mathrm{SO}_{4}$ to each well. Absorbance was followed at $492 \mathrm{~nm}$ (Lichtenstein et al., 1998).

\section{Results}

\section{Biotinylated and fluorescent probes for $\mathrm{p} 75$}

Biotinylation of NGF provides a convenient tag for monitoring NGF trafficking with a wide range of different probes. Most biotinylation protocols are targeted to amino groups in proteins, but unfortunately the amino side chains in NGF are crucial for binding to the p75 receptor (Ibanez, 1995). We therefore developed a protocol to biotinylate carboxyl side groups in NGF, using amino-biotin and EDC to activate and derivatize carboxyl groups. The modified NGF was purified by reverse-phase HPLC, and biotinylation was confirmed by Western blot analysis with avidin-peroxidase (Fig. 1A).

NGFb was able to compete with the binding of ${ }^{125} \mathrm{I}-\mathrm{NGF}$ to PC12 cells in the same dose range as native NGF (Fig. $1 B$ ), and native NGF competed with binding of NGFb to nnr5 cells that express p75 but not TrkA (Fig. 1C). NGFb bound TrkA transiently expressed in COS cells (Fig. $1 D$ ) and activated TrkA in the same effective dose range as native NGF (Fig. $1 E$ ). Finally, NGFb induced differentiation of $\mathrm{PC} 12$ cells in a similar manner as native NGF (Fig. $1 F$ ). Thus, the biotinylated protein was shown to faithfully mimic native NGF with respect to receptor binding and cellular responses, confirming its use for our purposes.

A complementary tool to NGFb was provided by a fluorescein-labeled preparation of the MC192 monoclonal antibody (Chandler et al., 1984). MC192 binds to an extracellular epitope on rat $\mathrm{p} 75$, which is distinct from the binding site for NGF. Moreover, MC192 binding does not deleteriously affect NGF signaling in PC12 cells (Chandler et al., 1984; Heckers et al., 1994; Maliartchouk and Saragovi, 1997) or neurons (Brann et al., 1999).

\section{P75 internalizes to a transferrin-positive endosome}

Although internalization of the p75 receptor has been demonstrated in glial cells (Kahle and Hertel, 1992), to date there is no convincing evidence for ligand-induced p75 internalization in neurons or neuronal cell lines. We addressed this question by incubating PC12 cells with MC192-FITC $(3 \mu \mathrm{g} / \mathrm{ml})$ in the presence of NGF (20 nM) and transferrin-Alexa-647 $(60 \mu \mathrm{g} / \mathrm{ml}$. The high NGF concentration was chosen to ensure maximal internalization of neurotrophin receptors. After $15 \mathrm{~min}$ at $37^{\circ} \mathrm{C}, \mathrm{MC1} 192-$ FITC was associated primarily with the cell surface (Fig. $2 \mathrm{~A}$, top panel), similar to the distribution observed in cells treated for 90 min at $4^{\circ} \mathrm{C}$ (data not shown). Tranferrin-Alexa-647 internalized within $15 \mathrm{~min}$ at $37^{\circ} \mathrm{C}$. After $60-90 \mathrm{~min}$ at $37^{\circ} \mathrm{C}$, internalization of MC192-FITC was evident (Fig. 2A, middle panel), and the label colocalized with transferrin-Alexa-647. At steady state $\left(120-180 \mathrm{~min}\right.$ at $\left.37^{\circ} \mathrm{C}\right), \mathrm{MC} 192-$ FITC and transferrin-Alexa-647 extensively colocalized (Fig. $2 \mathrm{~A}$, bottom panel), and this was also confirmed by a confocal three-dimensional reconstruction of serial $z$-planes (Fig. $2 D$ ). Quantification revealed up to $80 \%$ colocalization at the $90-180 \mathrm{~min}$ time points (Fig. $2 \mathrm{C}$ ). We calculated the initial rate of internalization by regression analysis from the internalization curves shown in Figure $2 E$ (Shogomori and Futerman, 2001). The internalization rate thus calculated for the p75 receptor $\left(t_{1 / 2} \sim 46 \mathrm{~min}\right)$ proved to be approximately three times that of transferrin $\left(t_{1 / 2} \sim 17 \mathrm{~min}\right)$. The kinetics of internal-
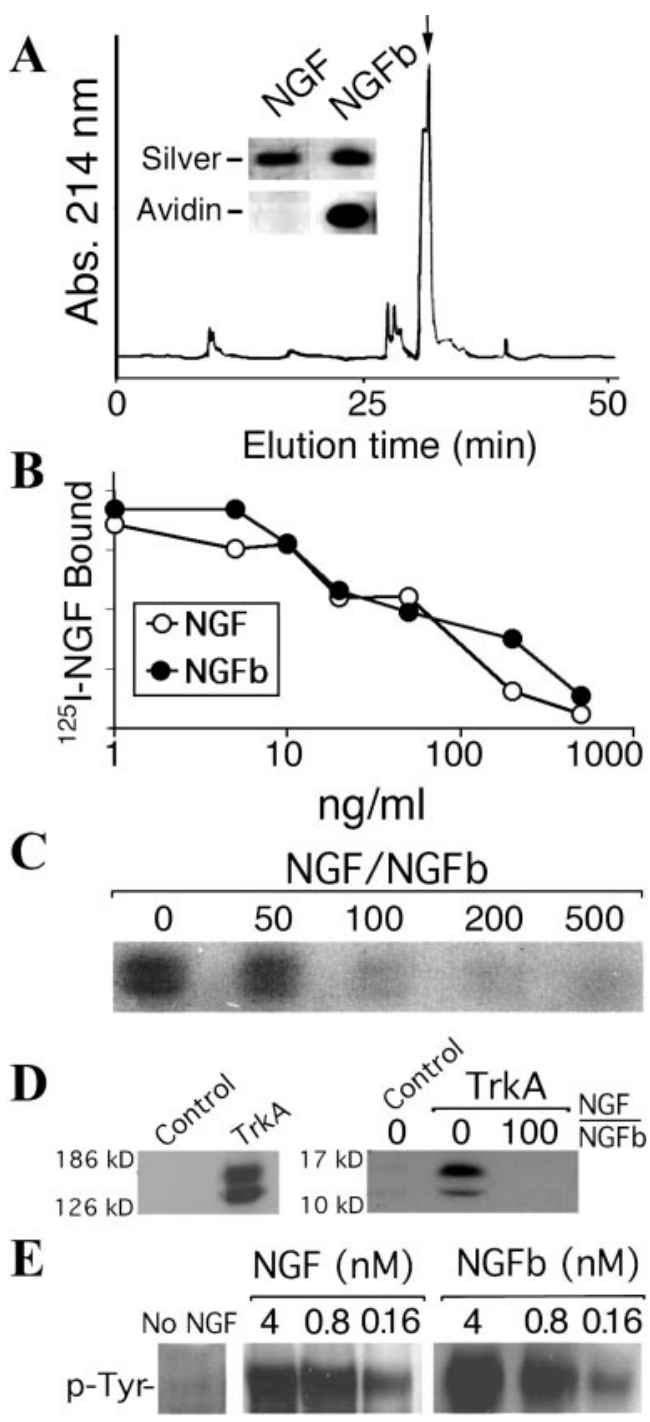

F

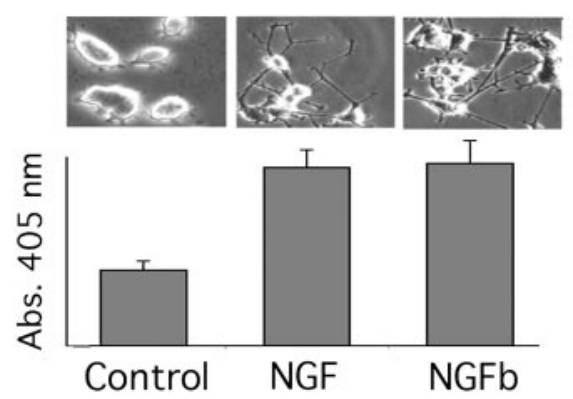

Figure 1. Generation of a stably labeled bioactive derivative of NGF. A, NGF was labeled with biotin through the $\mathrm{COOH}$ groups using as reactants amino-biotin and EDC; the biotinylated NGF was separated by HPLC on a Vydac C 4 reverse phase column. Inset, NGFb was run in an SDS-PAGE gel and silver stained or blotted and detected with avidin peroxidase. $B, N G F$ and NGFb displacement of ${ }^{125}$ I-NGF bound to PC12 cells ( $E_{50}$ NGF, $2.8 \pm 0.4 \mathrm{~nm}$; $\left.\mathrm{EC}_{50} \mathrm{NGFb}, 2.2 \pm 0.6 \mathrm{~nm}\right) . \mathrm{C}$, nnr5 cells were incubated at $4^{\circ} \mathrm{C}$ with $6 \mathrm{~nm} \mathrm{NGFb}$ and different ratios of NGF, as shown. NGFb was precipitated from cell homogenates on streptavidin magnetic beads and visualized on Western blots with avidin peroxidase. D, Left panel, Western blot to show TrkA expression in transfected COS cells. Right panel, Control or TrkA-transfected $\mathrm{COS}$ cells were incubated with 4 nM NGFb at $4^{\circ} \mathrm{C}$, with or without 100 -fold excess NGF, and binding was visualized as described above. E, PC12 cells were incubated with different concentrations of NGF or NGFb for $15 \mathrm{~min}$, and TrkA tyrosine phosphorylation was determined. F, Morphological differentiation of PC12 cells after $3 \mathrm{~d}$ of treatment with 2 nм NGF or NGFb concomitant with increased acetyl cholinesterase activity as a cholinergic differentiation marker. 


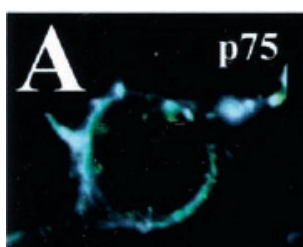

$15 \mathrm{~min}$
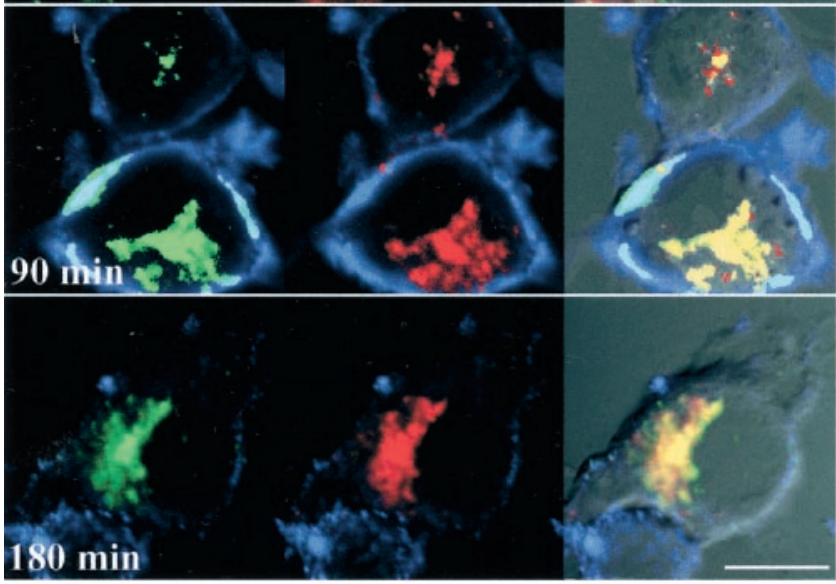

B
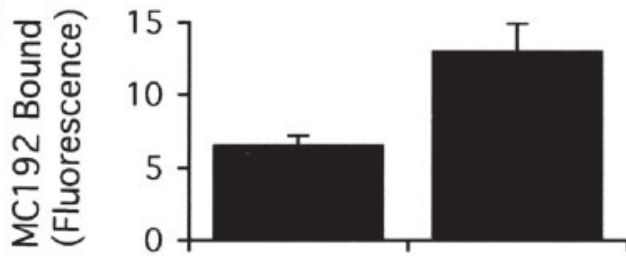

MC192

MC192 + NGF
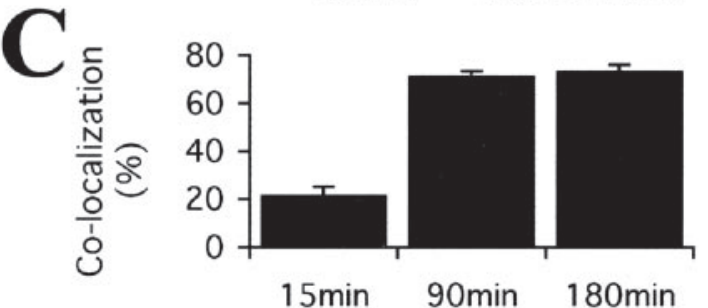

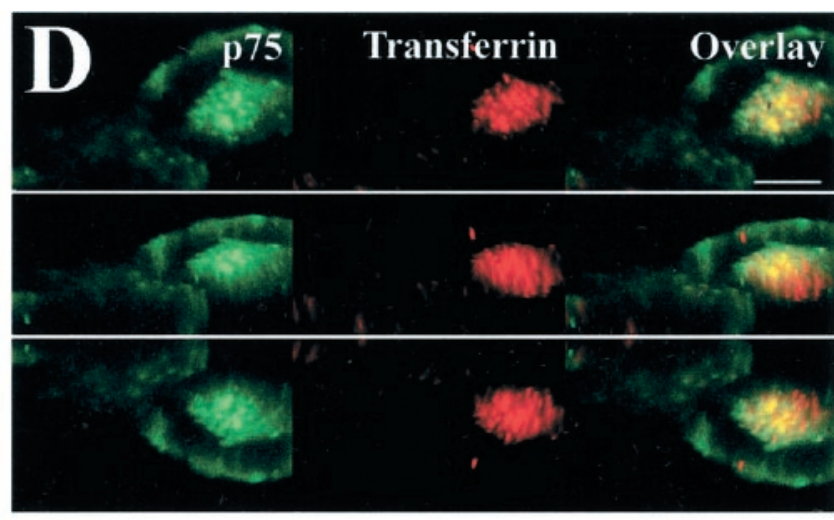

$\Delta$ p75 receptor

E

- Transferrin

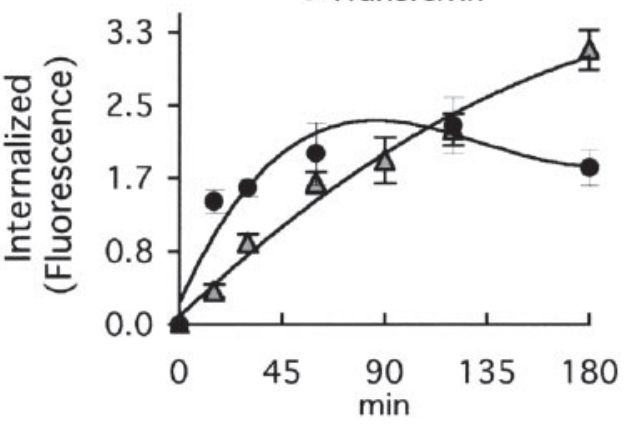

- NGF $\quad \triangle$ BDNF $\quad \square-$ No NT

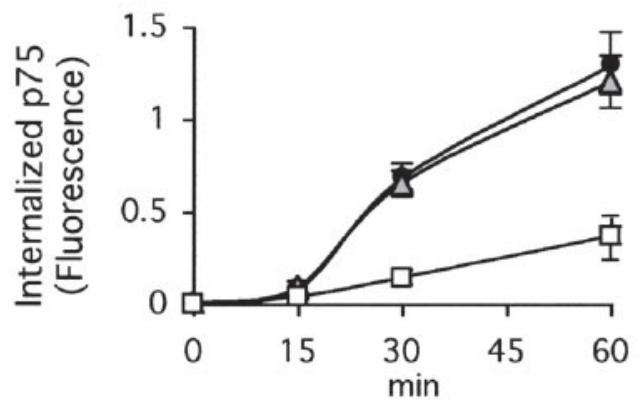

Figure 2. p75 is internalized to a transferrin-positive endosome in a ligand-dependent manner. $A$, Visualization of the internalization of p75 (labeled with MC192-FITC; $3 \mu \mathrm{g} / \mathrm{ml}$, green) in the presence of NGF ( $20 \mathrm{~nm}$ ) and transferrin-Alexa-647 (red, $60 \mu \mathrm{g} / \mathrm{ml})$ by confocal microscopy on PC12 cells. After incubation, cells were fixed and incubated with anti-mouse-RRX (1:250, blue) to label cell-surface $\mathrm{p} 75$. B, Binding of MC192 to PC12 cells at $4^{\circ} \mathrm{C}$ in the presence or absence of NGF (20 nM). C, Degree of colocalization of p75 and transferrin in the recycling endosome; $12-15$ cells were analyzed for time point. D, Confocal three-dimensional reconstruction of serial z-planes of a PC12 cell incubated for 120 min at $37^{\circ} \mathrm{C}$ with MC192-FITC, NGF, and transferrin-Alexa-647. Different rotation angles are shown. Scale bar, $10 \mu \mathrm{m}$. E, Internalization kinetics of $\mathrm{p} 75$ labeled with MC192-FITC as shown in $A$ (relative fluorescence, normalized to cell surface $p 75$ ), and transferrin-Alexa647 (arbitrary fluorescence units) in the presence of NGF (20 nM); 12-15 cells were analyzed for each time point. F, p75 internalization kinetics in differentiated PC12 treated with MC192-FITC (3 $\mu \mathrm{g} / \mathrm{ml})$ and $6 \mathrm{~nm}$ of the indicated neurotrophin. The plots show average \pm SEM for $12-15$ cells at each time point.

ization of MC192-FITC in the presence of 6 nM NGF in differentiated versus cycling PC12 was similar $\left(t_{1 / 2} \sim 46 \mathrm{~min}\right.$ in cycling PC12 vs $t_{1 / 2} \sim 50 \mathrm{~min}$ in differentiated PC12) (Fig. $2 E, F$ ).

\section{p75 internalization is ligand dependent and}

TrkA independent

MC192-FITC internalization in PC12 cells in the absence of ligand was very slow and equally potentiated by NGF or BDNF (Fig. $2 F$ ). NGF-induced internalization of MC192-FITC was also observed in nnr5 cells, in which the label accumulated in transferrin-positive vesicles after $2 \mathrm{hr}$ at $37^{\circ} \mathrm{C}$ (Fig. $3 A$ ). These data indicate that ligand-induced p75 internalization does not require trk activation.
To obtain an independent measurement of p75 internalization kinetics, we used NGFb to monitor internalization in PC12 and nnr5 cells. Consistent with the MC192-FITC data in PC12, $\mathrm{NGFb}$ was internalized less rapidly by nnr 5 cells (that express $\mathrm{p} 75$ only) than by PC12 cells that express both trk and p75 $\left(t_{1 / 2} \sim 18\right.$ min for PC12 vs $t_{1 / 2} \sim 48 \mathrm{~min}$ for nnr5) (Fig. $3 C$ ). The total cellular levels of p75 after NGF treatment remained constant after up to $3 \mathrm{hr}$ of incubation (Fig. $3 B$ ), suggesting that p75 does not undergo degradation.

The p75 colocalization with transferrin at incubation times above 30 min suggests that p75 is a recycling receptor. We therefore investigated whether NGFb recycles back to the cell surface in both PC12 and nnr5 cells by allowing NGFb to internalize for 


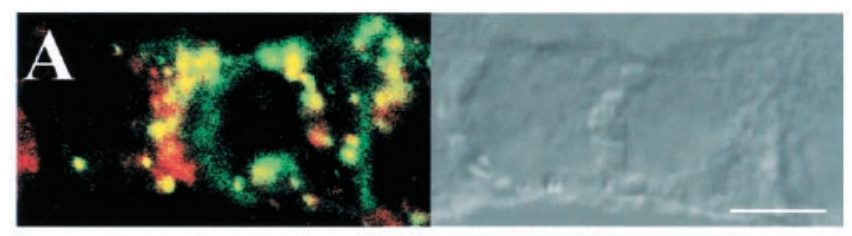

B $\begin{array}{lllllll}\text { AW } & 10 & 20 & 30 & 60 & 120 & 180\end{array}$
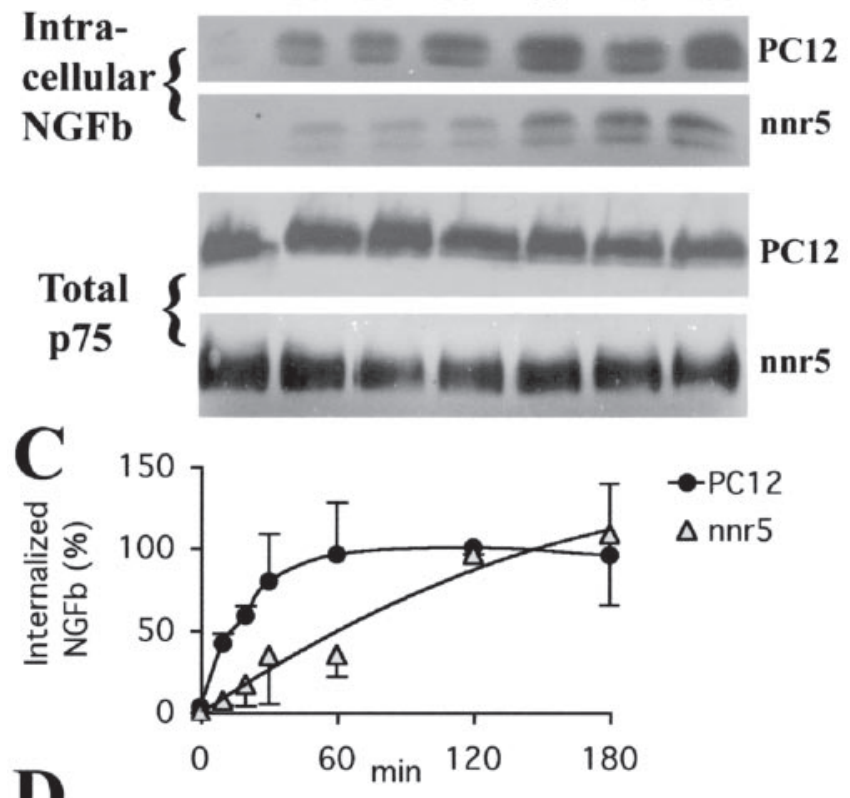

D
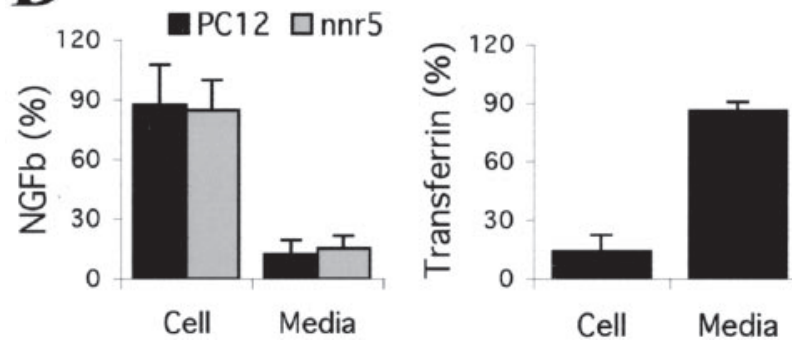

Figure 3. Slow internalization and limited recycling of p75-bound NGF. A, Confocal microscopy of nnr5 cells treated for $120 \mathrm{~min}$ at $37^{\circ} \mathrm{C}$ with MC192-FITC (green, $3 \mu \mathrm{g} / \mathrm{ml}$ ) and transferrin-Alexa-594 (red, $60 \mu \mathrm{g} / \mathrm{ml})$, in the presence of $6 \mathrm{~nm}$ NGF. Colocalized ligands appear in yellow. Scale bar, $10 \mu \mathrm{m}$. B, Top panels, PC12 and nnr5 cells incubated with 4 or $6 \mathrm{~nm}$, respectively, of NGFb, at different internalization times before acid wash. NGFb was precipitated from cell homogenates on streptavidin magnetic beads and visualized on Western blot with avidin peroxidase. Bottom panel, Corresponding total $p 75$ levels in cell lysates. C, Internalization kinetics of NGFb in $\mathrm{PC} 12$ versus nnr5 (average $\pm \mathrm{SEM} ; n=3$ ). $D$, Recycling of NGFb in $\mathrm{PC} 12$ and nnr5. The cells were incubated with $4-6 \mathrm{~nm} \mathrm{NGFb} \mathrm{for} 60 \mathrm{~min}$ at $4^{\circ} \mathrm{C}$, followed by $2 \mathrm{hr}$ at $37^{\circ} \mathrm{C}$. Cells were then acid washed and incubated for $1 \mathrm{hr}$ at $37^{\circ} \mathrm{C}$ with 100 -fold excess of NGF. Approximately $15 \%$ of the NGFb was recovered in the incubation media in both cases. Approximately $90 \%$ of transferrin-HRP recycled under similar conditions in PC12 cells.

$2 \mathrm{hr}$ at $37^{\circ} \mathrm{C}$, followed by acid wash and incubation of the cells in fresh medium in the presence of 100-fold excess of NGF. Relatively little NGFb $(\sim 15 \%)$ was recovered in the incubation media, and a substantial amount was retained intracellularly. This contrasted with transferrin recycling, in which $90 \%$ was recovered in the cell media (Fig. 3D). These results suggest that the recycling kinetics of NGF is inherently slow. Slow recycling kinetics has been described previously for other receptors that also accumulate in transferrin-positive endosomes (Innamorati et al., 1998; Chatterjee et al., 2001; Innamorati et al., 2001).
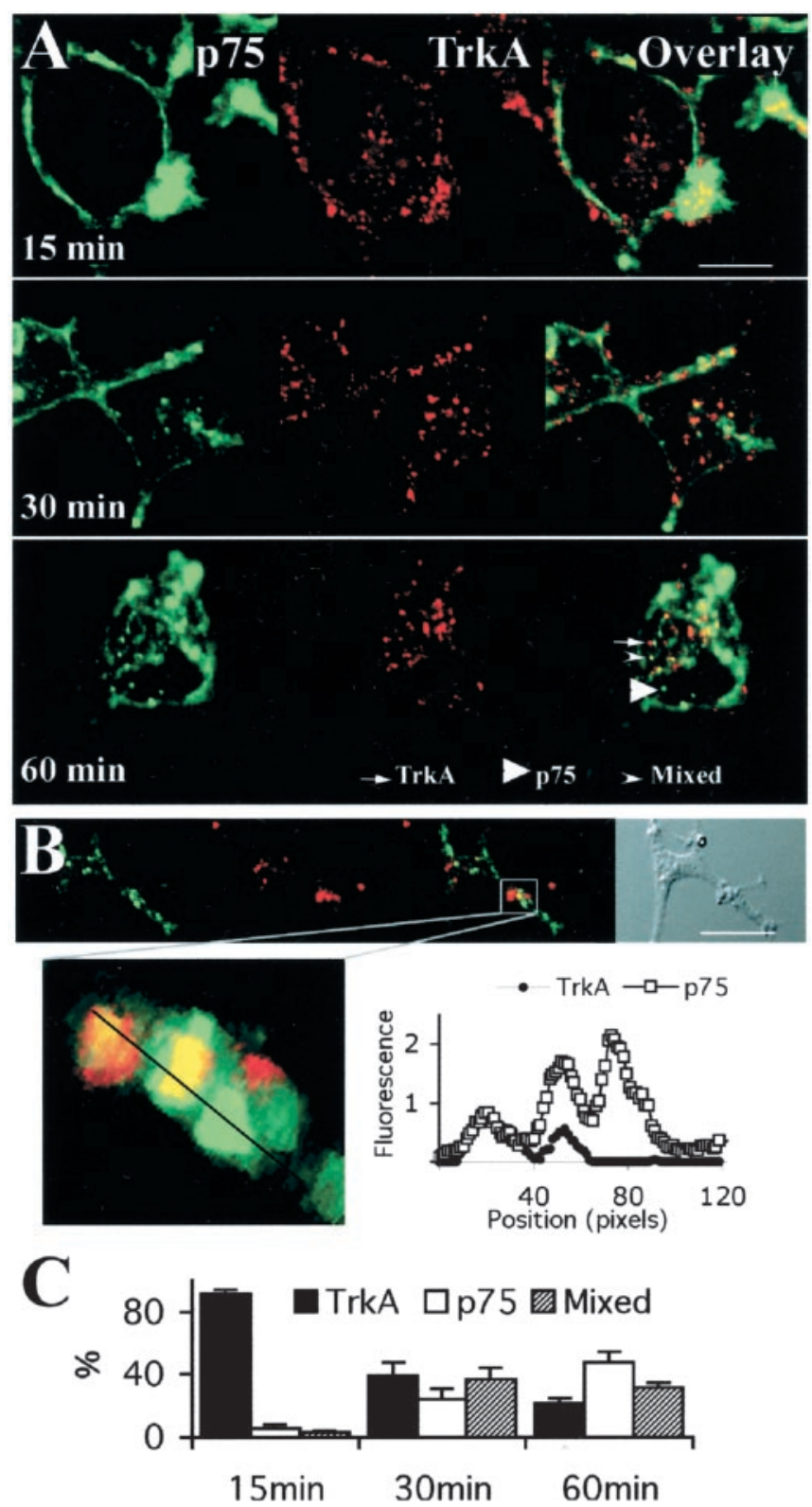

Figure 4. Distinct $\mathrm{p} 75$ and TrkA internalized vesicles in differentiated PC12 cells. $A$, Confocal microscopy of differentiated PC12 cells treated with MC192-FITC ( $3 \mu \mathrm{g} / \mathrm{ml}$, green), the ligandmimicking r-TrkA antibody (1:500), and BDNF (4 nM). Cells were incubated with primary antibodies for 60 min at $4^{\circ} \mathrm{C}$, anti-rabbit-Cy $5\left(1: 250\right.$, red) and BDNF $(4 \mathrm{~nm})$ for $30 \mathrm{~min}$ at $4^{\circ} \mathrm{C}$, and for the indicated times at $37^{\circ} \mathrm{C}$ in the presence of BDNF ( $\left.4 \mathrm{~nm}\right)$. B, Visualization of p75 and TrkApositive vesicles in the growth cone of differentiated $\mathrm{PC} 12$ treated as in $A$ ( 60 min internalization). Scale bar, $10 \mu \mathrm{m}$. Bottom panel, Confocal three-dimensional reconstruction of serial $z$-planes of the indicated region. The graph on the right shows fluorescence intensity levels along the line drawn through the three vesicles present in the boxed region of the growth cone. C, Quantification of the experiment shown in A. The presence of p75 or TrkA, or both, was quantified for individual vesicles by measuring the fluorescence intensity of each dye (FITC for p75 and (y5 for TrkA), summing $\sim 15$ vesicles per cell and $12-15$ cells for each time point.

Internalization kinetics and vesicle accumulation of TrkA versus p75

The kinetics of $\mathrm{NGFb}$ internalization in PC12 versus nnr5 suggested that TrkA receptors internalize faster than p75 receptors. We assessed this possibility by performing a cointernalization experiment of TrkA and p75 in differentiated PC12. TrkA internalization was induced and visualized with an NGF-mimicking anti-TrkA antibody (Clary et al., 1994), whereas p75 internaliza- 

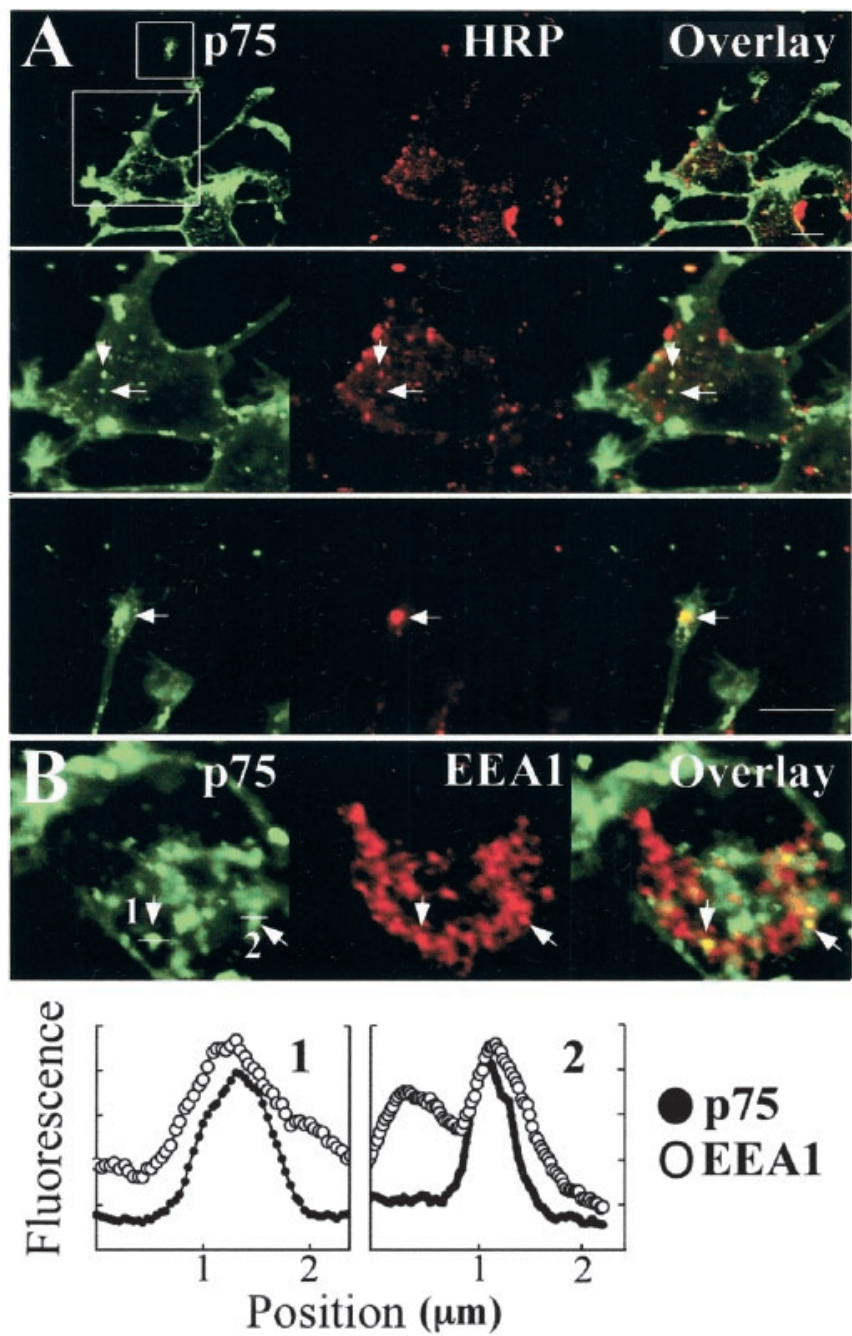
OEEA1

Figure 5. Internalized p75 compared with early endosome markers in the initial phase of internalization. A, Differentiated $\mathrm{PC} 12$ cells were incubated 30 min at $37^{\circ} \mathrm{C}$ with MC192-FITC (green, $3 \mu \mathrm{g} / \mathrm{ml}$ ), NGF $(6 \mathrm{~nm})$, and $2 \mathrm{mg} / \mathrm{ml}$ HRP (a fluid phase marker) and then fixed and incubated with anti-HRP-RRX (1:100, red). Bottom panels, Magnification of the cell body and growth cone boxed in the top panel. Scale bar, $10 \mu \mathrm{m}$. Arrows indicate colocalization. B, Differentiated PC12 were incubated $60 \mathrm{~min}$ at $37^{\circ} \mathrm{C}$ with MC192-FITC (green, $3 \mu \mathrm{g} / \mathrm{ml}$ ) and NGF (6 $\mathrm{nm}$ ) and then fixed and immunostained for EEA1 (an early endosome marker). Arrows indicate vesicles positive for EEA1 and p75 in the periphery of the cell. Bottom panel, Fluorescence intensity levels of the two vesicles indicated in $B$ corroborate $p 75$ and EEA1 colocalization in these vesicles.

tion was induced by BDNF and visualized with MC192-FITC. After $15 \mathrm{~min}$ at $37^{\circ} \mathrm{C},>80 \%$ of the labeled vesicles were TrkA positive and did not contain p75 (Fig. $4 A, C$ ). At longer incubation times $(60 \mathrm{~min})$, three vesicle populations were observed: TrkA only, p75 only, or mixed (Fig. 4). Interestingly, all three populations could also be discerned in PC12 growth cones (Fig. $4 B$ ).

\section{Internalized p75 is sorted to early endosomes via} clathrin-coated pits

In the well characterized clathrin-mediated endocytic pathway, endocytosed molecules are delivered to sorting or early endosomes and then trafficked to the recycled endosomal compartment or to late endosomes and lysosomes for degradation. The fact that internalized p75 colocalized with transferrin at steady state strongly suggests that p75 avoids the degradation route and

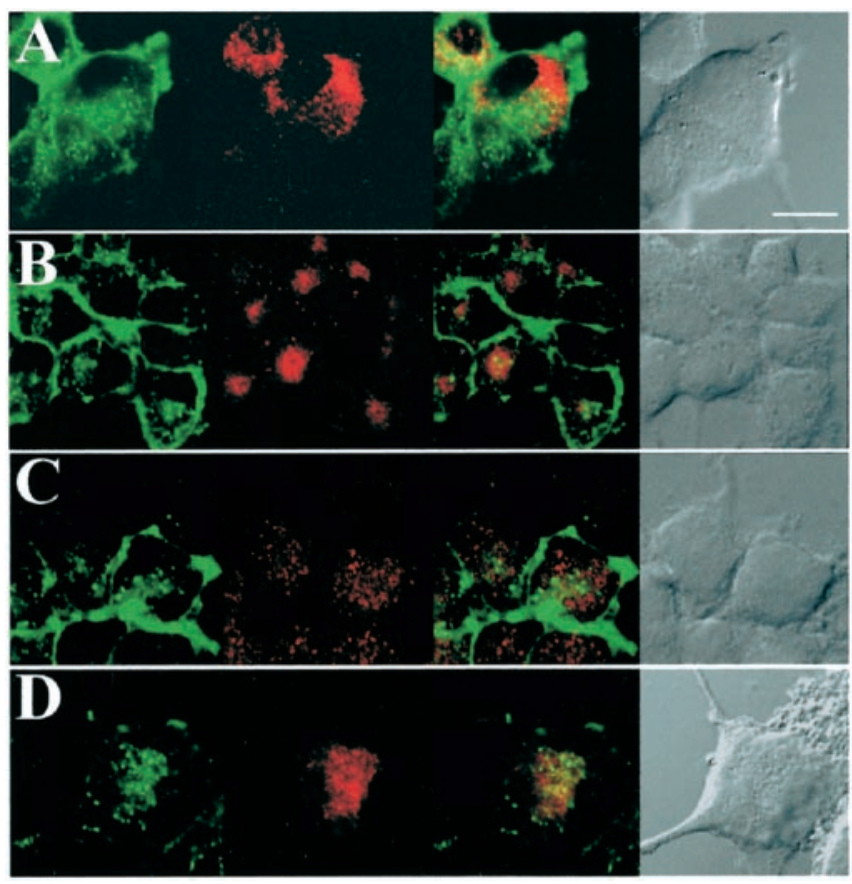

Figure 6. Internalized p75 compared with acidic organelle markers. $A$, Differentiated PC12 cells were incubated for $15 \mathrm{~min}$ at $37^{\circ} \mathrm{C}$ with $2 \mathrm{mg} / \mathrm{ml} \mathrm{HRP}$ and then washed and incubated for $3 \mathrm{hr}$ at $37^{\circ} \mathrm{C}$ with MC192-FITC (green, $3 \mu \mathrm{g} / \mathrm{ml}$ ) and NGF (6 nM). Cells were fixed and incubated with anti-HRP-RRX antibody (1:100, red). B, C, Differentiated PC12 cells were incubated for $3 \mathrm{hr}$ at $37^{\circ} \mathrm{C}$ with MC192-FITC (green, $3 \mu \mathrm{g} / \mathrm{ml}$ ) and NGF ( $6 \mathrm{~nm}$ ) and then fixed and incubated with anti-rab7 ( $B$ ) or anti-cathepsin-D ( $C$ and developed with anti-rabbit-RRX (1:500, red). D, Differentiated PC12 cells were incubated for $3 \mathrm{hr}$ at $37^{\circ} \mathrm{C}$ with MC192-FITC (green, $3 \mu \mathrm{g} / \mathrm{ml}$ ) and NGF ( $6 \mathrm{~nm})$, followed by 5 min at $37^{\circ} \mathrm{C}$ with lysotracker Red DND-99, washed, and fixed. Scale bar, $10 \mu \mathrm{m}$.

accumulates in the recycling compartment (Gruenberg and Maxfield, 1995; Mukherjee et al., 1997). Early endosomes accumulate fluid phase markers such as HRP. To test whether p75 passes through an early endosome compartment before reaching the recycling endosome, we applied HRP $(2 \mathrm{mg} / \mathrm{ml})$ together with MC192-FITC in the presence of NGF for $30 \mathrm{~min}$ and visualized the HRP with anti-HRP-RRX. As shown in Figure $5 A$, both markers colocalized in a subset of vesicles in the cell body and growth cones of differentiated PC12. In addition, endosomes at the cell periphery that were positive for $\mathrm{p} 75$ were also positive for EEA1 (Fig. 5B), a specific marker for early endosomes (Mills et al., 1998). In contrast, at longer incubation times (3 hr), MC192FITC does not colocalize with HRP in lysosomes (Fig. 6A) or with lysosomal or late endosomal markers (Fig. 6B, C). Furthermore, MC192-positive vesicles did not accumulate significant amounts of lysotracker dye, which labels acidic organelles such as the lysosome (Fig. 6D).

To investigate whether the internalization of p75 is mediated by clathrin-coated pits, we tested the association of p75 with clathrin matrices by co-patching experiments. p75 was patched on the cell surface by incubating PC12 cells with MC192-FITC, NGF, and anti-mouse secondary antibody. Cells were then fixed and immunostained for Clathrin $\mathrm{HC}$, revealing extensive copatching of clathrin with the p75 receptor (Fig. $7 A$ ). We then repeated the MC192-FITC internalization assay using two protocols that inhibit the formation of clathrin matrices: potassium depletion (Larkin et al., 1983) and cytosol acidification (Sandvig et al., 1987). These treatments inhibit clathrin-mediated endocy- 

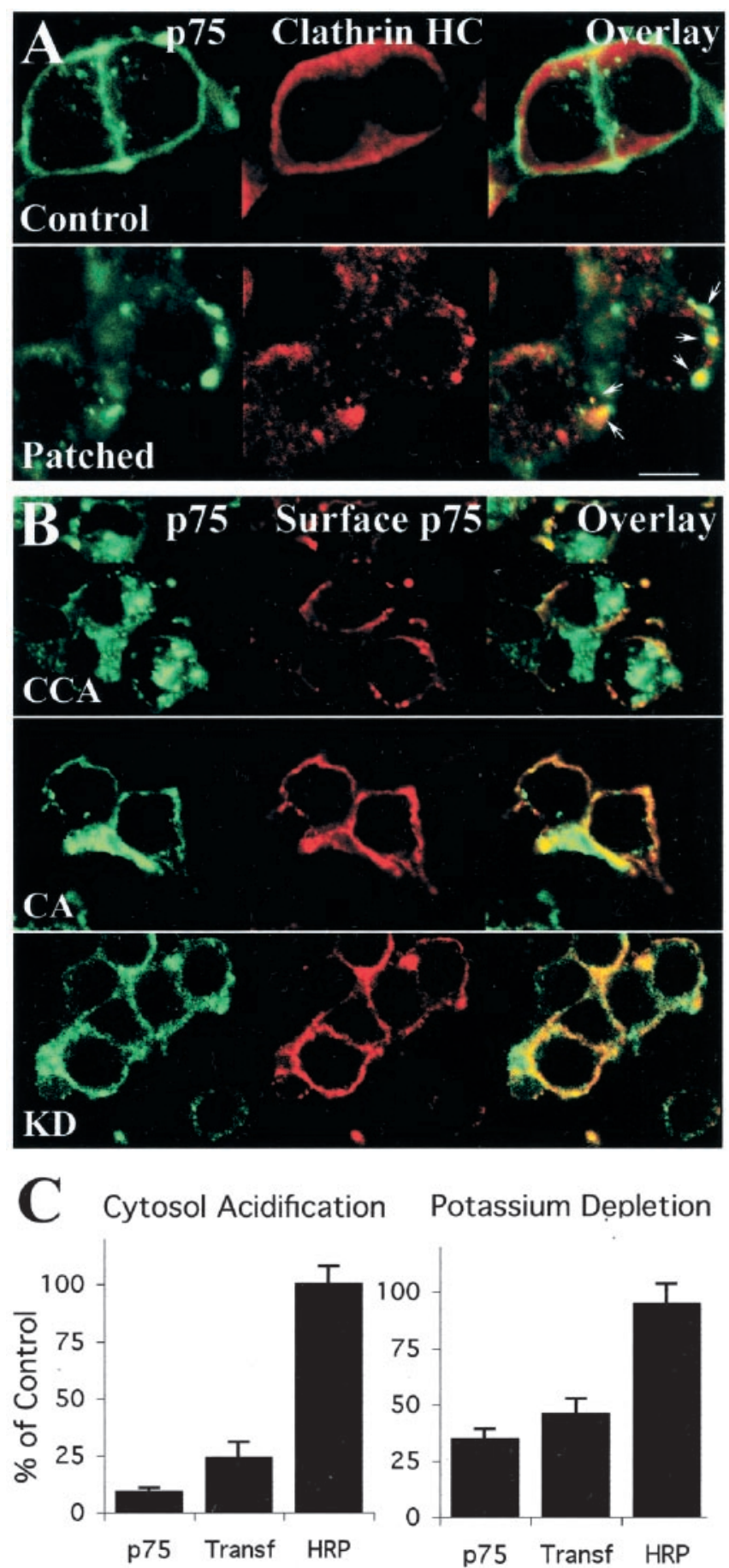

Figure 7. p75 internalization involves clathrin-mediated endocytosis. $A$, Co-patching of p75 with clathrin. Control, PC12 cells were treated for 30 min with MC192-FITC ( $3 \mu \mathrm{g} / \mathrm{ml}$, green) and NGF ( $4 \mathrm{nM})$ at $37^{\circ} \mathrm{C}$, fixed, and immunostained for Clathrin $\mathrm{HC}$ (developed with anti-goatCy5, red). Patched, PC12 cells were treated for 15 min with MC192-FITC ( $3 \mu \mathrm{g} / \mathrm{ml}$, green) and NGF ( $4 \mathrm{~nm}$ ) at $37^{\circ} \mathrm{C}$, followed by 30 min with rabbit-anti mouse $(1: 25)$ at $4^{\circ} \mathrm{C}$ and also incubated for $15 \mathrm{~min}$ at $37^{\circ} \mathrm{C}$, fixed, and treated as in control. Arrows indicate co-patching of p75 and clathrin. Scale bar, $10 \mu \mathrm{m}$. B, Inhibition of clathrin-mediated endocytosis. PC12 cells were incubated with MC192-FITC ( $3 \mu \mathrm{g} / \mathrm{ml}$, green) in the presence of NGF $(6 \mathrm{~nm})$ for $90 \mathrm{~min}$ at $37^{\circ} \mathrm{C}$, and clathrin-dependent endocytosis was inhibited as described in Materials and Methods. After treatment, cells were fixed and incubated with an anti-mouse-RRX antibody to label p75 remaining on the cell surface (red). CCA, Control cytosol acidification; CA, cytosol acidification; KD, potassium depletion. The control for potassium depletion was similar to the CCA (data not shown). C, Quantification of the degree of internalization of p75, transferrin (Transf), or HRP under the different treatments.
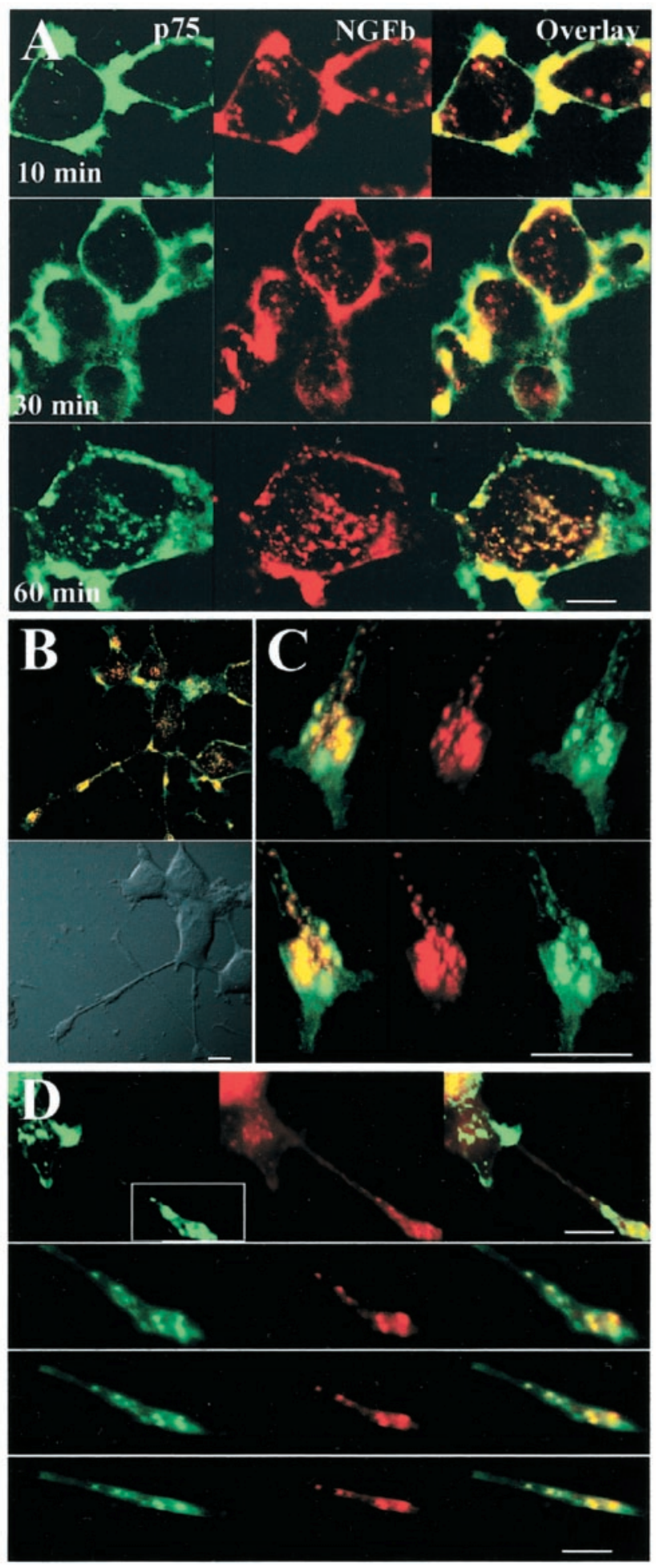

Figure 8. Cointernalization of $\mathrm{p} 75$ and NGF in common endocytic vesicles. $A$, Confocal microscopy on cell bodies of differentiated PC12 cells treated with MC192-FITC ( $3 \mu \mathrm{g} / \mathrm{ml}$, green) and NGFb (20 nM) for $90 \mathrm{~min}$ at $4^{\circ} \mathrm{C}$, washed and incubated for $30-45 \mathrm{~min}$ at $4^{\circ} \mathrm{C}$ with streptavidin-Alexa-647 (1:500, red), and then incubated for the indicated times at $37^{\circ} \mathrm{C}$. Scale bar, $10 \mu \mathrm{m} . B$, Merged confocal images of differentiated $\mathrm{PC} 12$ cells treated as described in $A$ and incubated for $60 \mathrm{~min}$ at $37^{\circ} \mathrm{C}$. Scale bar, $10 \mu \mathrm{m}$. C, Confocal three-dimensional reconstruction of serial $z$-planes of a growth cone of differentiated $\mathrm{PC} 12$ cell treated as described in $A$. Different rotation angles are shown. Scale bar, $5 \mu \mathrm{m}$. D, Top panel, Confocal microscopy on differentiated PC12 cells treated for $60 \mathrm{~min}$ at $37^{\circ} \mathrm{C}$ with MC192-FITC (green, $3 \mu \mathrm{g} / \mathrm{ml}$ ) and CTX-B-Alexa-594 (red, $5 \mu \mathrm{g} / \mathrm{ml}$ ) in the presence of $6 \mathrm{~nm}$ NGF. Scale bar, $10 \mu \mathrm{m}$. Bottom panels, Confocal threedimensional reconstruction of serial $z$-planes of the region of the growth cone boxed in the top panel. Different rotation angles are shown. Scale bar, $5 \mu \mathrm{m}$. 
A

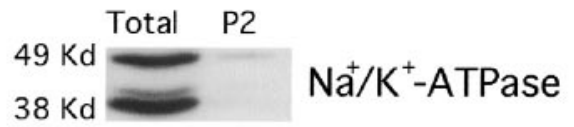

B O Gradient $1 \Delta$ Gradient 1-Gradient $2 \quad$ Gradient 2
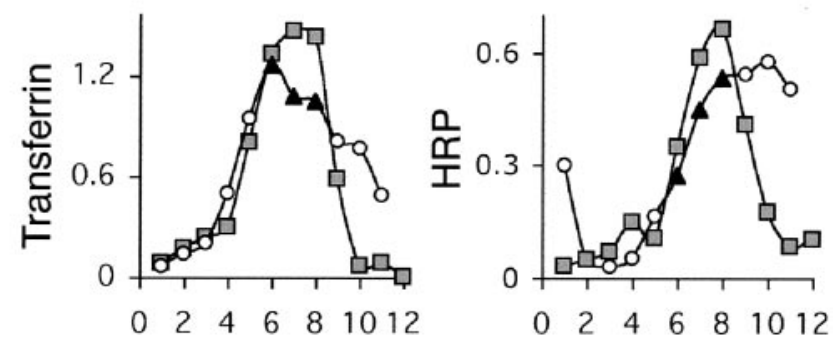

C
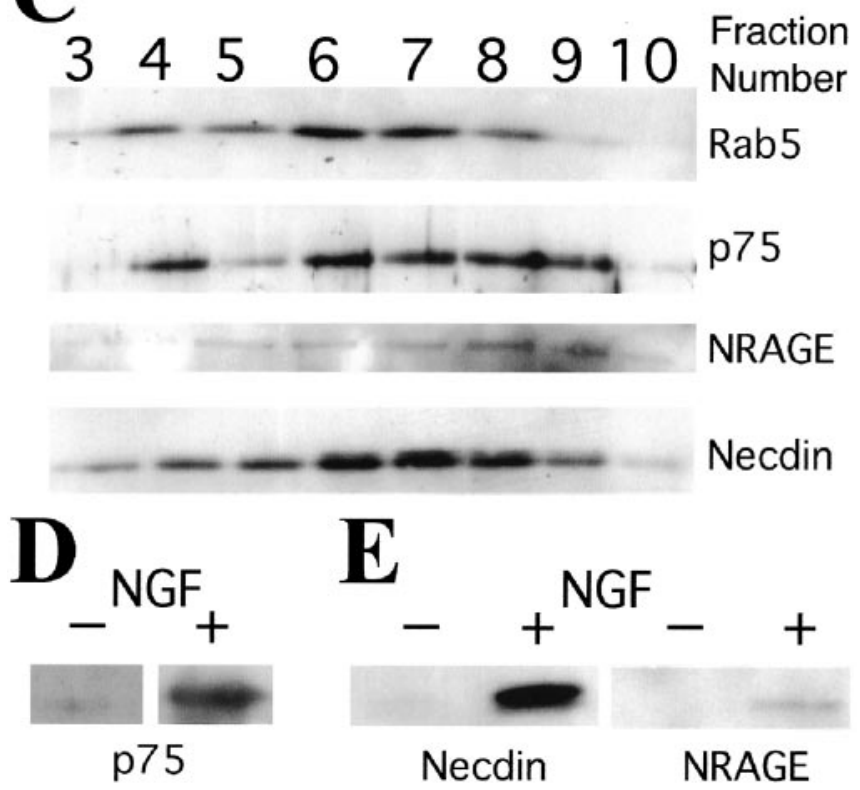

Figure 9. NGF induces the association of $\mathrm{p} 75$ and its MAGE interactors in endosomes. PC12 cells were treated for $2 \mathrm{hr}$ at $37^{\circ} \mathrm{C}$ with NGF ( $4 \mathrm{~nm}$ ) and $15 \mathrm{~min}$ at $37^{\circ} \mathrm{C}$ with HRP ( $1 \mathrm{mg} / \mathrm{ml}$ ) in the presence of NGF, or $1 \mathrm{hr}$ at $37^{\circ} \mathrm{C}$ with transferrin-HRP $(8 \mu \mathrm{g} / \mathrm{ml})$. Cells were then homogenized in 320 mm sucrose, 20 mm HEPES, pH 7.4, buffer with a ball homogenizer. A postnuclear supernatant was prepared and centrifuged for $1 \mathrm{hr}$ at 35,000 rpm in a TLS 55 rotor over a cushion of $1 \%$ Ficoll to obtain a $P 2$ pellet. $A$, Plasma membrane contamination assessed by Western blot for the $\beta 1$ subunit of $\mathrm{Na}^{+} / \mathrm{K}^{+}$-ATPase, $50 \mu \mathrm{g}$ of protein per lane. $B, \mathrm{P} 2$ was resuspended in $1 \mathrm{ml}$ of $320 \mathrm{~mm}$ sucrose, $20 \mathrm{~mm}$ HEPES, pH 7.4, and loaded in an $11 \mathrm{ml}$ linear Ficoll gradient (1-16\%). The gradient was centrifuged for $3 \mathrm{hr}$ at 35,000 rpm in an SW41 rotor, and $1 \mathrm{ml}$ fractions were manually collected from the top. HRP or transferrin-HRP was used to define the early/recycling compartment (gradient 1), and the three peak fractions indicated in black were pooled for a second fractionation. The second gradient was $9 \mathrm{ml}$ of linear Ficoll (3-16\%) and centrifuged for $3 \mathrm{hr}$ at 35,000 rpm in an SW41 rotor. One milliliter fractions were manually collected from the top (gradient 2) and found to be free of detectable plasma membrane marker (data not shown). C, Western blots of gradient 2 fractions from cells treated with NGF for 2 hr. Aliquots (70 $\mu \mathrm{l})$ were separated on 12\% PAGE and probed for rab5, p75, NRAGE, or necdin. D, p75 levels in the peak endosomal pool of PC12 treated or not treated with NGF (equal protein loaded). E, Coimmunoprecipitation of MAGE interactors with p75 in endosomes. Fractions 5-10 of gradient 2 were pooled, diluted eightfold with $320 \mathrm{~mm}$ sucrose, $20 \mathrm{~mm}$ HEPES, pH 7.4, and centrifuged for 10-12 hr at 35,000 rpm in an SW41 rotor. The sedimented endosomes were additionally centrifuged for $1 \mathrm{hr}$ at 55,000 rpm in a TLS 55 rotor and lysed with $20 \mathrm{~mm}$ Tris- $\mathrm{HCl}, \mathrm{pH} 8.0,150 \mathrm{~mm} \mathrm{NaCl}, 0.1 \%$ Igepal, $10 \%$ glycerol, and protease inhibitors. p75 was immunoprecipitated with the MC192 antibody, and Western blots of precipitates were probed for NRAGE or necdin. Representative results from three (NRAGE) or two (necdin) experiments are shown. tosis without preventing endocytosis mediated by other processes such as caveolae-dependent mechanisms (Subtil et al., 1994). We first verified binding of MC192-FITC under both experimental conditions and then proceeded to monitor internalization. Under both conditions, MC192-FITC internalization is inhibited in a similar manner as transferrin, a classical clathrin-mediated internalization marker (Fig. $7 B, C$ ). HRP internalization via nonclathrin-dependent mechanisms, such as micropinocytosis, was not inhibited by these treatments (Fig. 7C).

\section{Evidence for a p75 signaling endosome}

To determine whether internalized p75 is active in PC12 cell endosomes, we investigated whether p75 internalized together with NGFb, visualizing the latter with streptavidin-Alexa-647. At short internalization intervals (10-30 min), we observed primarily NGFb-positive vesicles without p75, suggesting that these represent NGF-TrkA complexes (Fig. 8A). At longer time points (e.g., $1 \mathrm{hr}$ ), extensive colocalization of $\mathrm{NGFb}$ and p75 could be seen. Colocalization of $\mathrm{NGFb}$ and $\mathrm{p} 75$ was also found in neurites and growth cones of differentiated PC12 (Fig. 8 B, C). The endocytic compartment labeled with p75 and NGFb in the growth cone is also positive for the B-subunit of cholera toxin (CTX-B) (Fig. 8D). CTX-B binds to GM1 gangliosides in lipid rafts and is used as a retrograde transport tracer in the nervous system. In addition, CTX-B traverses the same endosomal compartment as receptor-bound ligands internalized via clathrin-mediated endocytosis (Tran et al., 1987; Nichols and Lippincott-Schwartz, 2001; Shogomori and Futerman, 2001). Thus, p75 and NGF accumulate together in the recycling endosomes and CTX-B-positive vesicles in the growth cone.

p75 does not posses intrinsic catalytic activities, therefore its biological effects are mediated by forming complexes with intracellular interactors (Barker, 1998; Hempstead, 2002), including members of the MAGE gene family (Salehi et al., 2000, 2002; Tcherpakov et al., 2002). Necdin, a MAGE family member, associates with p75 in a ligand-dependent manner and has a slow kinetics of association compared with other p75 interactors such as TRAF6 (Khursigara et al., 1999; Tcherpakov et al., 2002). To directly assess whether internalized p75 is associated with MAGE proteins on endosomes, we performed subcellular fractionation of PC12 cells to isolate early/recycling endosomes. We followed a modification of a previously described protocol (Blagoveshchenskaya et al., 1999; Blagoveshchenskaya and Cutler, 2000), as detailed in Materials and Methods (Fig. 9A,B). The endosome peak from NGF-stimulated PC12-necdin cells was positive for rab5, p75, NRAGE (endogenously expressed in PC12), and necdin (Fig. 9C). p75 levels in the endosomes were markedly increased by NGF (Fig. 9D). Coimmunoprecipitation from endosomal fractions showed that both necdin and NRAGE co-precipitated with p75 in an NGF-dependent manner (Fig. 9E). Thus, p75 is internalized together with its ligand to the recycling compartment where it associates with NRAGE and necdin, forming a p75-signaling endosome.

\section{Discussion}

In this study, we have demonstrated ligand-induced internalization of p75 and have shown that liganded p75 associates with intracellular MAGE interactors in the endosomal compartment of PC12 cells, thus suggesting that specific components of $\mathrm{p} 75$ signaling take place in a signaling endosome. In addition, we have presented evidence that p75 internalizes through the clathrinmediated internalization pathway to the recycling endosome but 
at distinct kinetics from TrkA, thus indicating that p75-signaling endosomes may be distinct from trk-signaling endosomes.

Monitoring the internalization and trafficking of p75-ligand complexes requires the use of selectively tagged ligands or probes for the complex. Most of the previous studies of neurotrophinreceptor internalization have relied primarily on preparations of neurotrophins labeled with radioactive iodine (Eveleth and Bradshaw, 1992; Kahle et al., 1994; Gargano et al., 1997). Although iodinated neurotrophins provide a highly sensitive probe caused by the high-specific activities obtainable in labeling and the relative ease of detection of ${ }^{125} \mathrm{I}$, there are inherent limitations to this approach (i.e., the short half-life of iodinated proteins and their reduced stability). Nonradioactive labeling of neurotrophins has been attempted previously by a number of groups with varying degrees of success. Neet and colleagues described a detailed protocol for fluorescein labeling of NGF; however, an unexpected quenching limited the use of this preparation (Kasaian et al., 1994). A recent preliminary report described the use of rhodamine-NGF to follow neuronal retrograde transport in vivo (Weible et al., 2001). Unfortunately, the labeling protocol of Weible et al. (2001) was targeted to amine groups that are crucial for NGF binding to p75 (Ibanez, 1995). To obtain a useful and stably labeled NGF that retains the capacity to bind to p75, we devised a biotinylation strategy targeted to carboxyl groups on the protein. Carboxyl groups in NGF have been successfully labeled previously with fluorescent high molecular weight dextrans (Gatzinsky et al., 2001). Our protocol leads to incorporation of an average of approximately nine biotins on carboxyl groups in each NGF dimer, whereas it retains both TrkA- and p75-binding properties of the modified NGF. The labeled NGF was stable and could be visualized or pulled down with various avidin- or streptavidin-based reagents, thus providing a highly versatile tool for studies of internalization and trafficking. This was complemented by the use of MC192-FITC as a selective fluorescent probe for $\mathrm{p} 75$, thus providing an additional and independent possibility for monitoring p75 internalization.

p75 internalization proceeds via clathrin-coated pits to early endosomes, with subsequent transfer to the recycling compartment. Internalization occurs in both cycling and postmitotic differentiated cells, and in the latter can also be observed in the processes and terminals. p75 and NGF colocalize in endosomes in the cell body and terminals, suggesting that internalized p75 may be activated. Intriguingly, the kinetics of internalization of ligand-bound p75 is slower than that for classical rates of clathrin-mediated endocytosis, such as those measured for the transferrin receptor. Moreover, p75-NGF internalization proceeds at a rate approximately one-third $\left(t_{1 / 2} \sim 42-50 \mathrm{~min}\right)$ than that of NGF-TrkA. The different rates of internalization of p75 and TrkA define different populations of endocytic vesicles in the cell body and growth cone of differentiated PC12 cells, which contain TrkA only, p75 only, or a mixed population of both receptors.

In the clathrin-mediated endocytic pathway, endocytosed molecules are delivered to the sorting endosome and then trafficked to the recycling endosome or the late endosome-lysosome pathway (Gruenberg and Maxfield, 1995; Mellman, 1996). If activated p75 transports an NGF-mediated retrograde signal, it must avoid degradation in the axon. Our data support this affirmation. Indeed, p75 and NGF avoid degradation and remain in the recycling endosome for at least up to $3 \mathrm{hr}$ after internalization. Likewise, NGF-TrkA internalized via clathrin (Howe et al., 2001) has been shown to avoid degradation (Zapf-Colby and Olefsky, 1998). In contrast to the neurotrophin receptors, the EGF recep- tor is not retrogradely transported and is efficiently degraded in the lysosomal pathway after ligand stimulation (Futter et al., 1996; Kao et al., 2001; Waterman et al., 2002). Thus, receptors that are retrogradely transported must first evade rapid degradation in the synaptic terminal. The recycling organelle in PC12 has been reported to contain synaptic vesicle components that recycle or sort to synaptic microvesicles (Lichtenstein et al., 1998). This raises the possibility that p75 normally recycles in the synaptic terminal, sharing a similar endosome as components of the synaptic vesicles. Ligand association with p75 might regulate interaction with specific docking proteins, which might then sort the receptor to the retrograde transport pathway. Indeed, the association of endosomal p75 with MAGE proteins supports this interesting possibility and suggests that internalized p75 might carry a signaling complex from the synaptic terminal to the cell body. Such a concept has been exemplified by the amyloid precursor protein that internalizes to recycling synaptic vesicles in primary cerebellar neurons and subsequently traffics retrogradely to the soma (Marquez-Sterling et al., 1997).

P75 and TrkA may form a high-affinity joint-binding complex for NGF (Esposito et al., 2001), raising the question of how these receptors internalize with different kinetics. Although we cannot rule out a fast-internalizing high-affinity complex in other cell types, the high excess of p75 over TrkA in PC12 cells (Urdiales et al., 1998) suggests that the majority of 775 receptors should be excluded from such a complex. Alternatively, the high-affinity complex may dissociate after ligand binding, allowing each receptor to follow separate kinetics of internalization. Nonetheless, because both p75-NGF and TrkA-NGF enter the cell via clathrinmediated endocytosis, their differential internalization kinetics is intriguing. Slow internalization kinetics has been observed in the past for GPi-linked receptors associated with lipid rafts (Chatterjee et al., 2001). Both p75 and TrkA have been found in these specialized microdomains (Huang et al., 1999), and internalized p75 colocalizes with the lipid raft marker CTX-B in differentiated $\mathrm{PC12}$. Thus, lipid rafts may regulate differential internalization of p75 versus TrkA (for example, via different affinities of the receptors for rafts). Notably, tetanus toxin-labeled retrograde trafficking vesicles in motor neurons have been reported to contain p75 (Lalli and Schiavo, 2002), and tetanus toxin is also associated with lipid rafts in the cell membrane (Herreros et al., 2001). Together, these studies might suggest that lipid rafts in the synaptic terminal regulate the sorting of retrograde-transported vesicles.

To summarize, our observations support the possibility that internalized neurotrophin-p75 complexes can act as signaling platforms in neuronal cells and may be incorporated to signaling endosomes. The differential kinetics of internalization of p75 complexes versus trk complexes may provide a mechanism for temporal separation between signaling endosomes containing each of these receptors. Such endosomes could thereby be shunted into a retrograde transport pathway of a neuron in a spatially separated manner, thus allowing differential signal transmission to the cell body.

\section{References}

Barker PA (1998) p75NTR: a study in contrasts. Cell Death Differ 5:346-356.

Berger-Sweeney J, Stearns NA, Murg SL, Floerke-Nashner LR, Lappi DA, Baxter MG (2001) Selective immunolesions of cholinergic neurons in mice: effects on neuroanatomy, neurochemistry, and behavior. J Neurosci 21:8164-8173.

Bhattacharyya A, Watson FL, Bradlee TA, Pomeroy SL, Stiles CD, Segal RA (1997) Trk receptors function as rapid retrograde signal carriers in the adult nervous system. J Neurosci 17:7007-7016. 
Blagoveshchenskaya AD, Cutler DF (2000) Sorting to synaptic-like microvesicles from early and late endosomes requires overlapping but not identical targeting signals. Mol Biol Cell 11:1801-1814.

Blagoveshchenskaya AD, Hewitt EW, Cutler DF (1999) A complex web of signal-dependent trafficking underlies the triorganellar distribution of P-selectin in neuroendocrine PC12 cells. J Cell Biol 145:1419-1433.

Brann AB, Scott R, Neuberger Y, Abulafia D, Boldin S, Fainzilber M, Futerman AH (1999) Ceramide signaling downstream of the p75 neurotrophin receptor mediates the effects of nerve growth factor on outgrowth of cultured hippocampal neurons. J Neurosci 19:8199-8206.

Bronfman FC, Moechars D, Van Leuven F (2000) Acetylcholinesterasepositive fiber deafferentation and cell shrinkage in the septohippocampal pathway of aged amyloid precursor protein london mutant transgenic mice. Neurobiol Dis 7:152-168.

Butowt R, von Bartheld CS (2001) Sorting of internalized neurotrophins into an endocytic transcytosis pathway via the Golgi system: ultrastructural analysis in retinal ganglion cells. J Neurosci 21:8915-8930.

Chandler CE, Parsons LM, Hosang M, Shooter EM (1984) A monoclonal antibody modulates the interaction of nerve growth factor with PC12 cells. J Biol Chem 259:6882-6889.

Chatterjee S, Smith ER, Hanada K, Stevens VL, Mayor S (2001) GPI anchoring leads to sphingolipid-dependent retention of endocytosed proteins in the recycling endosomal compartment. EMBO J 20:1583-1592.

Clary DO, Weskamp G, Austin LR, Reichardt LF (1994) TrkA cross-linking mimics neuronal responses to nerve growth factor. Mol Biol Cell 5:549-563.

Curtis R, Adryan KM, Stark JL, Park JS, Compton DL, Weskamp G, Huber LJ, Chao MV, Jaenisch R, Lee KF (1995) Differential role of the low affinity neurotrophin receptor ( $\mathrm{p} 75)$ in retrograde axonal transport of the neurotrophins. Neuron 14:1201-1211.

Della-Bianca V, Rossi F, Armato U, Dal-Pra I, Costantini C, Perini G, Politi V, Della Valle G (2001) Neurotrophin p75 receptor is involved in neuronal damage by prion peptide 106-126. J Biol Chem 276:38929-38933.

Di Fiore PP, De Camilli P (2001) Endocytosis and signaling. An inseparable partnership. Cell 106:1-4.

Esposito D, Patel P, Stephens RM, Perez P, Chao MV, Kaplan DR, Hempstead BL (2001) The cytoplasmic and transmembrane domains of the p75 and Trk A receptors regulate high affinity binding to nerve growth factor. J Biol Chem 276:32687-32695.

Eveleth DD, Bradshaw RA (1992) Nerve growth factor nonresponsive pheochromocytoma cells: altered internalization results in signaling dysfunction. J Cell Biol 117:291-299.

Fainzilber M, Smit AB, Syed NI, Wildering WC, Hermann P, Van der Schors RC, Jimenez C, Li KW, Van Minnen J, Bulloch AG, Ibanez CF, Geraerts WP (1996) CRNF, a molluscan neurotrophic factor that interacts with the p75 neurotrophin receptor. Science 274:1540-1543.

Futter CE, Pearse A, Hewlett LJ, Hopkins CR (1996) Multivesicular endosomes containing internalized EGF-EGF receptor complexes mature and then fuse directly with lysosomes. J Cell Biol 132:1011-1023.

Gargano N, Levi A, Alema S (1997) Modulation of nerve growth factor internalization by direct interaction between $\mathrm{p} 75$ and TrkA receptors. J Neurosci Res 50:1-12.

Gatzinsky KP, Haugland RP, Thrasivoulou C, Orike N, Budi-Santoso AW, Cowen T (2001) p75 and TrkA receptors are both required for uptake of NGF in adult sympathetic neurons: use of a novel fluorescent NGF conjugate. Brain Res 920:226-238.

Ginty DD, Segal RA (2002) Retrograde neurotrophin signaling: Trk-ing along the axon. Curr Opin Neurobiol 12:268-274.

Grimes ML, Beattie E, Mobley WC (1997) A signaling organelle containing the nerve growth factor-activated receptor tyrosine kinase, TrkA. Proc Natl Acad Sci USA 94:9909-9914.

Gruenberg J, Maxfield FR (1995) Membrane transport in the endocytic pathway. Curr Opin Cell Biol 7:552-563.

Heckers S, Ohtake T, Wiley RG, Lappi DA, Geula C, Mesulam MM (1994) Complete and selective cholinergic denervation of rat neocortex and hippocampus but not amygdala by an immunotoxin against the p75 NGF receptor. J Neurosci 14:1271-1289.

Heerssen HM, Segal RA (2002) Location, location, location: a spatial view of neurotrophin signal transduction. Trends Neurosci 25:160-165.

Hempstead BL (2002) The many faces of p75(NTR). Curr Opin Neurobiol $12: 260-267$.

Herreros J, Ng T, Schiavo G (2001) Lipid rafts act as specialized domains for tetanus toxin binding and internalization into neurons. Mol Biol Cell 12:2947-2960.

Howe CL, Valletta JS, Rusnak AS, Mobley WC (2001) NGF signaling from clathrin-coated vesicles: evidence that signaling endosomes serve as a platform for the Ras-MAPK pathway. Neuron 32:801-814.

Huang CS, Zhou J, Feng AK, Lynch CC, Klumperman J, DeArmond SJ, Mobley WC (1999) Nerve growth factor signaling in caveolae-like domains at the plasma membrane. J Biol Chem 274:36707-36714.

Hutson LD, Bothwell M (2001) Expression and function of Xenopus laevis p75(NTR) suggest evolution of developmental regulatory mechanisms. J Neurobiol 49:79-98.

Ibanez CF (1995) Neurotrophic factors: from structure-function studies to designing effective therapeutics. Trends Biotechnol 13:217-227.

Innamorati G, Sadeghi HM, Tran NT, Birnbaumer M (1998) A serine cluster prevents recycling of the V2 vasopressin receptor. Proc Natl Acad Sci USA 95:2222-2226.

Innamorati G, Le Gouill C, Balamotis M, Birnbaumer M (2001) The long and the short cycle. Alternative intracellular routes for trafficking of G-protein-coupled receptors. J Biol Chem 276:13096-13103.

Kahle P, Hertel C (1992) Nerve growth factor (NGF) receptor on rat glial cell lines. Evidence for NGF internalization via p75NGFR. J Biol Chem 267:13917-13923.

Kahle P, Barker PA, Shooter EM, Hertel C (1994) p75 nerve growth factor receptor modulates p140trkA kinase activity, but not ligand internalization, in PC12 cells. J Neurosci Res 38:599-606.

Kao S, Jaiswal RK, Kolch W, Landreth GE (2001) Identification of the mechanisms regulating the differential activation of the mapk cascade by epidermal growth factor and nerve growth factor in PC12 cells. J Biol Chem 276:18169-18177.

Kaplan DR, Miller FD (2000) Neurotrophin signal transduction in the nervous system. Curr Opin Neurobiol 10:381-391.

Kasaian MT, Jacobberger JW, Neet KE (1994) Flow cytometric analysis of fluorescein-labeled nerve growth-factor binding to A875 humanmelanoma cells. Exp Cell Res 210:77-85.

Khursigara G, Orlinick JR, Chao MV (1999) Association of the p75 neurotrophin receptor with TRAF6. J Biol Chem 274:2597-2600.

Kramer BM, Van der Zee CE, Hagg T (1999) P75 nerve growth factor receptor is important for retrograde transport of neurotrophins in adult cholinergic basal forebrain neurons. Neuroscience 94:1163-1172.

Kuruvilla R, Ye H, Ginty DD (2000) Spatially and functionally distinct roles of the PI3-K effector pathway during NGF signaling in sympathetic neurons. Neuron 27:499-512.

Lalli G, Schiavo G (2002) Analysis of retrograde transport in motor neurons reveals common endocytic carriers for tetanus toxin and neurotrophin receptor p75NTR. J Cell Biol 156:233-239.

Larkin JM, Brown MS, Goldstein JL, Anderson RG (1983) Depletion of intracellular potassium arrests coated pit formation and receptor-mediated endocytosis in fibroblasts. Cell 33:273-285.

Lee R, Kermani P, Teng KK, Hempstead BL (2001) Regulation of cell survival by secreted proneurotrophins. Science 294:1945-1948

Lichtenstein Y, Desnos C, Faundez V, Kelly RB, Clift-O’Grady L (1998) Vesiculation and sorting from PC12-derived endosomes in vitro. Proc Natl Acad Sci USA 95:11223-11228.

Lonze BE, Riccio A, Cohen S, Ginty DD (2002) Apoptosis, axonal growth defects, and degeneration of peripheral neurons in mice lacking CREB. Neuron 34:371-385.

MacInnis BL, Campenot RB (2002) Retrograde support of neuronal survival without retrograde transport of nerve growth factor. Science 295:1536-1539.

Maliartchouk S, Saragovi HU (1997) Optimal nerve growth factor trophic signals mediated by synergy of TrkA and p75 receptor-specific ligands J Neurosci 17:6031-6037.

Marquez-Sterling NR, Lo AC, Sisodia SS, Koo EH (1997) Trafficking of cell-surface beta-amyloid precursor protein: evidence that a sorting intermediate participates in synaptic vesicle recycling. J Neurosci 17:140-151.

Mellman I (1996) Membranes and sorting. Curr Opin Cell Biol 8:497-498.

Miller FD, Kaplan DR (2001) On Trk for retrograde signaling. Neuron 32:767-770

Mills IG, Jones AT, Clague MJ (1998) Involvement of the endosomal autoantigen EEA1 in homotypic fusion of early endosomes. Curr Bio $8: 881-884$. 
Mukherjee S, Ghosh RN, Maxfield FR (1997) Endocytosis. Physiol Rev 77:759-803.

Neet KE, Campenot RB (2001) Receptor binding, internalization, and retrograde transport of neurotrophic factors. Cell Mol Life Sci 58:1021-1035.

Nichols BJ, Lippincott-Schwartz J (2001) Endocytosis without clathrin coats. Trends Cell Biol 11:406-412.

Patapoutian A, Reichardt LF (2001) Trk receptors: mediators of neurotrophin action. Curr Opin Neurobiol 11:272-280.

Riccio A, Pierchala BA, Ciarallo CL, Ginty DD (1997) An NGF-TrkAmediated retrograde signal to transcription factor CREB in sympathetic neurons. Science 277:1097-1100.

Riccio A, Ahn S, Davenport CM, Blendy JA, Ginty DD (1999) Mediation by a CREB family transcription factor of NGF-dependent survival of sympathetic neurons. Science 286:2358-2361.

Ryden M, Hempstead B, Ibanez CF (1997) Differential modulation of neuron survival during development by nerve growth factor binding to the p75 neurotrophin receptor. J Biol Chem 272:16322-16328.

Salehi AH, Roux PP, Kubu CJ, Zeindler C, Bhakar A, Tannis LL, Verdi JM, Barker PA (2000) NRAGE, a novel MAGE protein, interacts with the p75 neurotrophin receptor and facilitates nerve growth factor-dependent apoptosis. Neuron 27:279-288.

Salehi AH, Xanthoudakis S, Barker PA (2002) NRAGE, a p75 neurotrophin receptor interacting protein, induces caspase activation and cell death through a JNK-dependent mitochondrial pathway. J Biol Chem 277:48043-48050.

Sandvig K, Olsnes S, Petersen OW, van Deurs B (1987) Acidification of the cytosol inhibits endocytosis from coated pits. J Cell Biol 105:679-689.

Senger DL, Campenot RB (1997) Rapid retrograde tyrosine phosphorylation of trkA and other proteins in rat sympathetic neurons in compartmented cultures. J Cell Biol 138:411-421.

Shogomori H, Futerman AH (2001) Cholera toxin is found in detergentinsoluble rafts/domains at the cell surface of hippocampal neurons but is internalized via a raft-independent mechanism. J Biol Chem 276:9182-9188.

Subtil A, Hemar A, Dautry-Varsat A (1994) Rapid endocytosis of interleukin 2 receptors when clathrin-coated pit endocytosis is inhibited. J Cell Sci 107:3461-3468.

Tcherpakov M, Bronfman FC, Conticello SG, Vaskovsky A, Levy Z, Niinobe M, Yoshikawa K, Arenas E, Fainzilber M (2002) The p75 neurotrophin receptor interacts with multiple MAGE proteins. J Biol Chem 277:49101-49104.
Tran D, Carpentier JL, Sawano F, Gorden P, Orci L (1987) Ligands internalized through coated or noncoated invaginations follow a common intracellular pathway. Proc Natl Acad Sci USA 84:7957-7961.

Tsui-Pierchala BA, Ginty DD (1999) Characterization of an NGF-P-TrkA retrograde-signaling complex and age-dependent regulation of TrkA phosphorylation in sympathetic neurons. J Neurosci 19:8207-8218.

Tuffereau C, Benejean J, Blondel D, Kieffer B, Flamand A (1998) Lowaffinity nerve-growth factor receptor (P75NTR) can serve as a receptor for rabies virus. EMBO J 17:7250-7259.

Urdiales JL, Becker E, Andrieu M, Thomas A, Jullien J, van Grunsven LA, Menut S, Evan GI, Martin-Zanca D, Rudkin BB (1998) Cell cycle phasespecific surface expression of nerve growth factor receptors TrkA and p75(NTR). J Neurosci 18:6767-6775.

von Bartheld CS, Williams R, Lefcort F, Clary DO, Reichardt LF, Bothwell M (1996) Retrograde transport of neurotrophins from the eye to the brain in chick embryos: roles of the p75NTR and trkB receptors. J Neurosci 16:2995-3008.

von Schack D, Casademunt E, Schweigreiter R, Meyer M, Bibel M, Dechant G (2001) Complete ablation of the neurotrophin receptor p75NTR causes defects both in the nervous and the vascular system. Nat Neurosci 4:977-978.

Waterman H, Katz M, Rubin C, Shtiegman K, Lavi S, Elson A, Jovin T, Yarden Y (2002) A mutant EGF-receptor defective in ubiquitylation and endocytosis unveils a role for Grb2 in negative signaling. EMBO J 21:303-313.

Watson FL, Heerssen HM, Moheban DB, Lin MZ, Sauvageot CM, Bhattacharyya A, Pomeroy SL, Segal RA (1999) Rapid nuclear responses to target-derived neurotrophins require retrograde transport of ligandreceptor complex. J Neurosci 19:7889-7900.

Watson FL, Heerssen HM, Bhattacharyya A, Klesse L, Lin MZ, Segal RA (2001) Neurotrophins use the Erk5 pathway to mediate a retrograde survival response. Nat Neurosci 4:981-988.

Weible Jr MW, Bartlett SE, Reynolds AJ, Hendry IA (2001) Prolonged recycling of internalized neurotrophins in the nerve terminal. Cytometry 43:182-188.

Yano H, Lee FS, Kong H, Chuang J, Arevalo J, Perez P, Sung C, Chao MV (2001) Association of Trk neurotrophin receptors with components of the cytoplasmic dynein motor. J Neurosci 21:RC125(1-7).

Zapf-Colby A, Olefsky JM (1998) Nerve growth factor processing and trafficking events following TrkA-mediated endocytosis. Endocrinology 139: 3232-3240. 